DOI 10.15290/cnisk.2018.01.04.01

DR HAB. AGNIESZKA SZUDAREK, PROF. US

orcid.org/0000-0002-6851-9808

Uniwersytet Szczeciński

\title{
Berliński międzynarodowy zjazd działaczek ruchu kobiecego w 1904 r. w świetle tygodników warszawskich
}

\section{Streszczenie}

W czerwcu 1904 r. w Berlinie miały miejsce konferencja założycielska Międzynarodowego Sojuszu na Rzecz Praw Wyborczych Kobiet (International Woman Suffrage Alliance, IWSA), zgromadzenie generalne Międzynarodowej Rady Kobiet (International Council of Women, ICW) oraz Międzynarodowy Kongres Kobiet (International Congress of Women). Wydarzenia te były szeroko komentowane w prasie, w tym także w tygodnikach warszawskich. Artykuł stanowi analizę tekstów omawiających te zdarzenia, które opublikowane zostały na łamach dziesięciu tygodników, różnych pod względem programowym. W większości ich autorkami były znane działaczki, m.in. Paulina Kuczalska-Reinschmit, Izabela Moszczeńska czy Teodora Męczkowska. Analiza poprzedzona jest omówieniem sytuacji w międzynarodowym ruchu kobiecym przed zjazdem berlińskim oraz charakterystyka tygodników, które zamieściły informacje na jego temat. Wymowa komentarzy prasowych podporzadkowana była profilowi czasopisma, co w niektórych przypadkach ograniczało autorki artykułów. Najbardziej poczytne tygodniki nie popierały równościowych projektów emancypacyjnych. Pozytywne komentarze zawierały głównie te pisma, które skierowane były do postępowej inteligencji - liberałów i socjalistów. Miały one jednak ograniczony nakład i słabe możliwości oddziaływania. Mimo nie zawsze przychylnych ocen omówienia berlińskiego zjazdu działaczek tygodniki upowszechniły program ruchu kobiecego, zwłaszcza jego aktywność na polu socjalnym i edukacyjnym.

Słowa kluczowe: międzynarodowy ruch kobiecy, prasa w Kongresówce, kwestia kobieca, niemiecki ruch kobiecy 


\title{
INTERNATIONAL GATHERING OF WOMEN'S MOVEMENT ACTIVISTS IN BERLIN IN 1904 AS PRESENTED IN WARSAW WEEKLY PRESS
}

\begin{abstract}
In June 1904, Berlin hosted the founding conference of the International Woman Suffrage Alliance (IWSA), the general assembly of the International Council of Women (ICW) and the International Congress of Women. These events were extensively discussed in the press, including Warsaw's weeklies. The article analyses the press coverage of these events in 10 weeklies with different programme agenda. Most of the authors were well-known female activists, such as Paulina Kuczalska-Reinschmit, Izabela Moszczeńska, and Teodora Męczkowska. The analysis is preceded by the overview of the international women's movement in the run-up to the Berlin gathering as well as the profile of each of the weeklies reporting it. The messages underpinning the press comments were dictated by the agenda of each paper, which in some cases limited their authors. Most widely-read weeklies did not support equality and emancipation-oriented projects. Favourable comments were expressed mostly by the papers read by progressive intellectuals - liberals and socialists. However, those weeklies had a rather limited circulation and abilities to make an impact. Although the opinions were not always positive, the coverage of the Berlin gathering of activists promoted the programme of the women's movement, especially its social and educational agendas.
\end{abstract}

Keywords: international women's movement, Congress Kingdom press, women's issues, German women's movement

\section{Wprowadzenie}

W czerwcu 1904 r. Berlin stał się centrum - jak to wówczas określano - wszechświatowego ruchu kobiecego. W stolicy Cesarstwa Niemieckiego spotkały się bowiem działaczki i zwolenniczki programów reform społecznych, socjalnych, politycznych i obyczajowych majacych na celu przedefiniowanie statusu oraz roli swojej płci. Jak donosiła ówczesna prasa, do Berlina przyjechało wiele kobiet $z$ różnych krajów, w tym również ze Stanów Zjednoczonych i Australii. Wydarzeniami, które przyciagnęły je nad Sprewę, były: konferencja założycielska Międzynarodowego Sojuszu na Rzecz Praw Wyborczych Kobiet (International Wo- 
man Suffrage Alliance, IWSA), zgromadzenie generalne Międzynarodowej Rady Kobiet (International Council of Women, ICW) oraz Międzynarodowy Kongres Kobiet (International Congress of Women). O ile dwa pierwsze przeznaczone były tylko dla członkiń, o tyle obrady Kongresu miały charakter publiczny i cieszyły się dużym zainteresowaniem, przykuwając również uwagę dziennikarzy, którzy podkreślali, iż w obradach każdego dnia bierze udział około 5 tys. kobiet. O „sejmie niewieścim” pisała też prasa warszawska, nie tylko gazety, lecz także różne pod względem zabarwienia ideowego tygodniki społeczno-polityczno-kulturalne, których redakcje były ośrodkami kształtujacymi opinię publiczną w Warszawie i na prowincji ${ }^{1}$.

Relacje $z$ Berlina wpisywały się w szerszy dyskurs nad tzw. kwestia kobieca, widoczny coraz wyraźniej w polskiej publicystyce i literaturze pięknej od lat siedemdziesiątych XIX w. Jego ramy tworzył spór między pozytywistami warszawskimi a konserwatystami, który później przerodził się w konflikt „postępowców” (głównie liberałów i socjalistów) $z$ „zachowawcami”". Początkowo projektom emancypacyjnym, zarówno umiarkowanym ( $\mathrm{tj}$. nieszermującym hasłem równouprawnienia kobiet i mężczyzn), jak i radykalnym (tj. opowiadającym się za równościa płci) rozwijanym w środowisku inteligencji miejskiej nie towarzyszyła szersza działalność organizacyjna ${ }^{3}$. Koniec XIX i pierwsze lata XX w. były raczej czasem dojrzewania tak idei, jak i samych kobiet do intensywnej aktywności społecznej, której zaczynem w Królestwie Polskim stała się rewolucja 1905-1907 i wiążące się z nią upolitycznienie kwestii kobiecej4. W tej sytuacji relacje na temat berlińskiego zjazdu działaczek zamieszczone w opiniotwórczych tygodnikach o różnej orientacji programowo-ideowej

1 Z. Kmiecik, Prasa warszawska w latach 1886-1904, Wrocław 1989, s. 5, 21-24; D. Adamczyk, Prasa jako narzędzie oddziaływania warszawskich środowisk opiniotwórczych i politycznych na prowincje $w$ II połowie XIX i poczatkach XX wieku (na przykładzie Kielc i guberni kieleckiej), „Kwartalnik Historii Prasy Polskiej” 1990, t. 29, z. 1, s. 71-82.

2 A. Jaszczuk, Spór pozytywistów z konserwatystami o przyszłość Polski 1870-1903, Warszawa 1986, s. 199-201; R. Blobaum, „Kwestia kobieca” w Królestwie Polskim (19001914) [w:] Działaczki społeczne, feministki, obywatelki... Samoorganizowanie sie kobiet na ziemiach polskich do 1918 roku (na tle porównawczym), red. A. Janiak-Jasińska, K. Sierakowska, A. Szwarc, Warszawa 2008, s. 37-56.

3 R. Blobaum, op. cit., s. 37-56.

4 K. Sierakowska, Ruch kobiecy a rewolucja 1905 roku [w:] Dziedzictwo rewolucji 19051907, red. A. Żarnowska [et al.], Warszawa-Radom 2007, s. 255-275. Zob. też: T. Stegner, Środowiska liberalne $w$ Królestwie Polskim wobec kwestii kobiecej $w$ dobie rewolucji lat 1905-1907 [w:] O kobietach. Studia i szkice. Wiek XIX i XX, red. J. Hoff, Rzeszów 2011, s. $103-119$. 
dają możliwość uchwycenia tego, jaki był stosunek poszczególnych redakcji do ruchu kobiecego jako szerszego, ponadnarodowego i zorganizowanego działania na rzecz przedefiniowania roli i statusu kobiet w modernizującej się rzeczywistości.

Celem artykułu jest więc określenie charakteru narracji towarzyszącej wspomnianym relacjom oraz ustalenie uwarunkowań mających wpływ na jej konstrukcję, głębię informacyjna, a zwłaszcza warstwę interpretacyjna, kluczową w kontekście teorii społecznego tworzenia rzeczywistości. Narracja ta nie była przecież indyferentna ${ }^{5}$. Nadawała znaczenie, które wzmacniało czy nawet budowało tożsamość odbiorców komunikatu, przyczyniając się, jeśli nie do upowszechnienia i zaakceptowania, to przynajmniej oswojenia określonego programu emancypacyjnego (umiarkowanego lub radykalnego) bądź antyemancypacyjnego. $\mathrm{W}$ tych okolicznościach istotne będzie więc poszukiwanie odpowiedzi na pytanie, na ile wymowa poszczególnych relacji była pochodna pogladów ich autorek i autorów, na ile zaś oczekiwań redakcji tygodników, względnie czytelników ${ }^{6}$ ? Idąc dalej, czy można poszczególnym typom tygodników przyporządkować konkretne cechy narracji lub też odnaleźć w relacjach elementy wspólne wpływajace na budowanie w świadomości społecznej określonego stosunku do ruchu kobiecego? Pamiętać należy także i o tym, że przekaz prasowy miał moc sprawcza, modelował rzeczywistość, w związku $z$ tym stanowił też narzędzie do transmisji wzorów postępowania, a więc w tym przypadku kierunków i form aktywności, które mogły zostać przeniesione do praktyki społecznej na ziemiach polskich $^{7}$. Kongresy służyły bowiem budowaniu pewnego rodzaju kultury opartej na wspólnocie wartości i dążeń, wzmacnianej wymianą doświad-

\footnotetext{
5 Por. K. Rosner, Narracja jako struktura rozumienia, „Teksty Drugie: teoria literatury, krytyka, interpretacja” 1999, t. 56, nr 3, s. 7-15.

6 Kwestia ta jest o tyle istotna, że nie zawsze poglądy formułowane w prasie były zbieżne z zawartymi w korespondencji prywatnej. Magdalena Gawin zwróciła uwagę na odmienne oceny Gabrieli Zapolskiej dotyczące paryskiego międzynarodowego kongresu kobiet w 1892 r. Na łamach „Przeglądu Tygodniowego” można było przeczytać, że „kobiety walczyły tu jako ludzie i głos ich był tak słuszny a silny, że tylko istoty nędzne i małe śmiać się i szydzić mogły”. W korespondencji prywatnej stwierdziła zaś, iż „było to zupełnie ciekawe widowisko. Skandal nad skandale! Najprzyzwoiciej prezentowały się Polki i Finki. Reszta było to coś takiego, że ja trzy dni konałam ze śmiechu. [...] Baby się kłóca, piszcza, docinają sobie. Mężczyźni kpią i coraz to jeden włazi na estradę i sieje niezgodę" (cyt. za: M. Gawin, Spór o równouprawnienie kobiet (1864-1919), Warszawa 2015, s. 205).

$7 \mathrm{Na}$ temat teorii społecznego tworzenia rzeczywistości Petera Bergera i Thomasa Luckmanna zob. A. Lech, Społeczne konstruowanie rzeczywistości obiektywnej, „Zeszyty Naukowe Politechniki Śląskiej”, seria: „Organizacja i Zarzadzanie” 2013, z. 65, s. 183-195.
} 
czeń i upowszechnianiem osiagnięć kobiet z różnych krajów. Regularne spotkania wpływały korzystnie na cyrkulację idei oraz kształtowanie przestrzeni komunikacyjnej wspartej na sieci powiąań osobistych i organizacyjnych sprzyjajacych kolonizowaniu nowych terytoriów ${ }^{8}$. Poszukiwaniu odpowiedzi na powyższe pytania musi więc towarzyszyć $z$ jednej strony nakreślenie sytuacji na warszawskim rynku prasowym, $z$ drugiej zaś okoliczności, w jakich doszło do międzynarodowego zjazdu działaczek organizacji kobiecych w Berlinie w 1904 r.

\section{Konteksty - tygodniki warszawskie na początku XX w.}

Do analizy wybrano artykuły zamieszczone na łamach tygodników społeczno-polityczno-kulturalnych wydawanych w Warszawie. Tygodniki te podzielono na kilka kategorii łaczacych tytuły o podobnym charakterze. Ze względu na zmiany, jakie zaszły na rynku prasowym w Warszawie przed rewolucja 1905-1907, wprowadzona przez Zenona Kmiecika typologia tygodników wydawanych na przełomie wieków w roku 1904 w dużej mierze nie przystawała już do rzeczywistości ${ }^{9}$. W związku $z$ tym na potrzeby niniejszej analizy pisma zostały podzielone na następujące grupy: 1) apolityczne magazyny ilustrowane: „Tygodnik Ilustrowany”10, „Wędrowiec”11, 2) magazyny literackie skierowane do kobiet: „Tygodnik

\footnotetext{
8 J. Gehmacher, Moderne Frauen, die Neue Welt und der alte Kontinent. Käthe Schirmacher reist im Netzwerk der Frauenbewegung, „Österreichische Zeitschrift für Geschichtswissenschaften" 2011, Bd. 22, H. 1, s. 19-20.

9 Z. Kmiecik, op. cit., s. 47 i n.

10 „Tygodnik Ilustrowany” wychodził w latach 1859-1939. W 1904 r. redagował go Józef Wolff. Pismo miało wówczas nakład 19 tys. egzemplarzy i było najpoczytniejszym magazynem ilustrowanym w Królestwie (Z. Kmiecik, „Tygodnik Mlustrowany” w latach 1886-1904, „Kwartalnik Historii Prasy Polskiej” 1982, t. 21, z. 3/4, s. 25-42).

11 „Wędrowiec” wydawany był w latach 1863-1906. W 1904 r. miał nakład 4100 egzemplarzy. Na jego czele stał wówczas Artur Oppman, który przekształcił tytuł z magazynu geograficzno-etnograficznego w magazyn ilustrowany społeczno-literacki (Idem, Oblicze społeczno-kulturalne tygodnika „Wędrowiec” (1886-1905), „Kwartalnik Historii Prasy Polskiej” 1983, t. 23, z. 4, s. 48).
} 
Mód i Powieści” ${ }^{2}$, „Bluszcz”13 oraz 3) organy liberalnej i radykalnej inteligencji (od demokratów po radykalnych socjalistów): „Prawda”" ${ }^{4}$, „Przegląd Tygodniowy”"15, „Niwa Polska”16, „Ogniwo”17 i „Głos”18. Dla uzyskania

12 „Tygodnik Mód i Powieści” wydawany był w latach 1862-1915. W 1904 r. miał nakład
7200 egzemplarzy. Redaktorem pisma w tym czasie był Wacław Podwiński. Nie formuło-
wało ono wówczas żadnego programu emancypacyjnego, chociaż redakcja śledziła ruch
kobiecy za granica i na ziemiach polskich, eksponujac zwłaszcza kwestie dotyczące pracy
zarobkowej kobiet z niższych warstw społecznych (J. Franke, Polska prasa kobieca w la-
tach 1820-1918. W kręgu ofiary i poświęcenia, Warszawa 1999, s. 79-92; Z. Kmiecik, Prasa warszawska..., op. cit., s. 144).

13 „Bluszcz” założony został w 1865 r. W 1904 r. na czele pisma, które wydawane było wówczas w nakładzie 4200 egzemplarzy, stał Marian Gawalewicz. Tytuł można uznać za trybunę umiarkowanego programu emancypacyjnego. „Bluszcz” ma już swoją bogata literaturę, zob. m.in. T. Kulak, Trybuna umiarkowanego feminizmu. „Bluszcz” pod kierownictwem redakcyjnym Zofii Seidlerowej w latach 1906-1918 [w:] Kobieta i media. Studia $z$ dziejów emancypacji kobiet, red. P. Perkowski, T. Stegner, Warszawa 2009, s. 70-92.

14 „Prawda. Tygodnik Polityczny, Społeczny i Literacki” (dalej: „Prawda”) ukazywała się w latach 1881-1915. Tytuł początkowo należał do wpływowych pism zwiazanych $z$ programem pozytywizmu warszawskiego. Na przełomie wieków stracił na znaczeniu, ale utrzymał status ważnego organu postępowców (liberałów). „Prawdę” założył i do 1900 r. prowadził Aleksander Świętochowski, który zachował jeszcze wpływ na jej kształt do roku 1902. Później nominalnie redaktorem naczelnym był Aleksander Dembowski, de facto jednak pismem kierowała Paulina Sieroszewska. W 1904 r. „Prawda” miała nakład 1800 egzemplarzy (W. Giełżyński, Prasa warszawska 1661-1914, Warszawa 1962, s. 368-369). 15 „Przegląd Tygodniowy Życia Społecznego, Literatury i Sztuk Pięknych” (dalej: „Przegląd Tygodniowy”) wydawany był w latach 1865-1904 przez Adama Wiślickiego. Tytuł miał charakter postępowy. W 1902 r. wychodził w nakładzie 2500 egzemplarzy (A. Garlicka, Matecznik niepokornych (Adam Wiślicki), „Kwartalnik Historii Prasy Polskiej” 1991, t. 30, z. 3/4, s. 71-84).

16 „Niwa Polska. Tygodnik Społeczny, Literacki, Polityczny i Naukowy” (dalej: „Niwa Polska”), do 1898 r. „Niwa”, ukazywała się w latach 1872-1905, początkowo jako pismo pozytywistów warszawskich. Program tygodnika ewoluował. W 1904 r. redakcja przechodziła $z$ pozycji umiarkowanych na radykalne, nadajac pismu charakter organu „czystych obyczajów” i „odrodzenia etycznego”. Wydawana była wówczas w nakładzie 1000 egzemplarzy. Na jej czele stał Wojciech Szukiewcz (M. Brykalska, „Niwa”, 1872-1905 [w:] Zwierciadło prasy. Czasopisma polskie XIX wieku o literaturze rosyjskiej, red. B. Galster [et al.], Wroclaw 1978, s. 246).

17 „Ogniwo. Tygodnik Naukowy, Społeczny i Polityczny” (dalej: „Ogniwo”) wydawane było w latach 1902-1905. Skupiało radykalna inteligencję zwiazaną z PPS. W 1904 r. jako redaktor wymieniany jest Leon Niemyski. W tym czasie pismo miało nakład 2300 egzemplarzy (M. Lipska, R. Loth, „Ogniwo” 1902-1905: bibliografia zawartości, „Materiały Bibliograficzne” 1957, t. 6, s. V-XXX; M. Sikorska-Kowalska, „Ogniwo” 1902-1905. „Legalna ekspozytura" PPS [w:] Polityka i politycy w prasie XX i XXI wieku. Prasa organizacji politycznych, red. M. Dajnowicz, A. Miodowski, Białystok 2017, s. 107-116).

18 "Głos. Tygodnik Naukowo-Literacki, Społeczny i Polityczny” (dalej: „Głos”) wydawany był w latach 1886-1905. W 1904 r. miał nakład 1875 egzemplarzy. Na jego czele stał wówczas Jan Władysław Dawid. Pismo od połowy 1904 r. było pod wpływem SDKPiL i zajęło skrajnie radykalna pozycję (W. Bułat, „Głos” Jana Władysława Dawida 1900-1905, „Rocznik Historii Czasopiśmiennictwa Polskiego” 1966, t. 5, z. 2, s. 66-83). 
niezbędnego kontekstu porównawczego badaniem objęto także relację czasopisma „Kraj” ${ }^{19}$, dla którego stworzono ostatnia, czwartą kategorię - periodyki konserwatywne. Tygodnik ten co prawda nie był wydawany w Warszawie, a w Petersburgu, ale odgrywał kluczowa rolę $\mathrm{w}$ tym nurcie ideowym. Co więcej, inne zbliżone do niego programowo tytuły, tak jak np. popularna prorodzinna warszawska „Biesiada Literacka” czy katolicka, zachowawcza „Kronika Rodzinna”, nie zauważyły wydarzeń berlińskich z czerwca 1904 r.

Wspomniane wyżej przemiany na rynku prasowym w Warszawie ukazuje m.in. sytuacja w redakcji tygodnika „Prawda” w omawianym okresie. Tytuł ten bowiem w pierwszych latach XX w. przechodził okres transformacji zwiazanej $z$ wycofywaniem się $z$ udziału $w$ jego redagowaniu Aleksandra Świętochowskiego. W 1902 r. „Prawda” znalazła się w rękach Pauliny Sieroszewskiej, bliskiej współpracowniczki Świętochowskiego ${ }^{20}$. Sieroszewska była zwiazana - jak podaje w swoich wspomnieniach jej brat Wacław - ze Zjednoczeniem Równouprawnienia Kobiet, szukajacym w tym czasie pisma, na którego łamach mogłoby propagować swój program. Wkrótce tygodnik stał się jednak nieoficjalnym organem powstałego w grudniu 1904 r. Związku Postępowo-Demokratycznego, który - co istotne $-\mathrm{w}$ swoim programie miał postulat równouprawnienia $\mathrm{płci}^{21}$.

Na przełomie XIX i XX w. również „Głos” i „Niwa Polska” zmieniły swoje oblicze programowe. Metamorfozy te wiązać należy $z$ widoczna w tym czasie zmianą pokoleniowa $\mathrm{w}$ gronie wiodacych publicystów i dziennikarzy warszawskich oraz znamienna dla tych lat polaryzacja w łonie orientacji demokratycznej i rozchodzeniem się dróg dotychcza-

19 „Kraj” wydawany był w latach 1882-1909. Do 1906 r. na jego czele stał założyciel Erazm Piltz. „Kraj” - poza dziennikiem „Słowo” - stanowił w tym czasie główny organ konserwatystów. W 1901 r. wydawany był w nakładzie 6350 egzemplarzy (Z. Kmiecik, Nowoczesny konserwatysta (Erazm Piltz), „Kwartalnik Historii Prasy Polskiej” 1991, t. 30, z. 3/4, s. 93; Idem, Problematyka społeczno-polityczna pism konserwatystów warszawskich (1908-1914), Ibidem, 1979, t. 18, z. 2, s. 68).

20 W 1902 r. z redakcji „Prawdy” odeszli socjaliści, którzy złożyli własne pismo „Ogniwo” (M. Brykalska, Aleksander Świętochowski redaktor „Prawdy”, Wrocław 1974, s. 152-153; M. Tobera, Poset prawdy (Aleksander Świętochowski), „Kwartalnik Historii Prasy Polskiej” 1991 , t. 30, z. 3/4, s. 65).

21 Ten krótki epizod $z$ dziejów „Prawdy” nie jest dostatecznie wyświetlony w literaturze przedmiotu, podobnie jak i działalność Zjednoczenia Równouprawnienia Kobiet. Sieroszewska kierowała „Prawda” do 1908 r., jednak tylko w latach 1906-1908 formalnie podpisywała się jako redaktor tytułu (W. Sieroszewski, Szkice podróżnicze i wspomnienia, Kraków 1959, s. 69-70; T. Stegner, op. cit., s. 106-107; M. Brykalska, Aleksander Świętochowski. Biografia, t. 2, Warszawa 1987, s. 38). 
sowych sojuszników wyrosłych na tradycji pozytywistycznej22. W tych okolicznościach radykalizująca się i zapatrzona w lewą stronę inteligencja potrzebowała nowych organów prasowych. Wokół „Głosu” skupiło się środowisko SDKPiL, a w połowie 1904 r. „Niwa Polska” otworzyła nowy i ostatni rozdział $\mathrm{w}$ swoich dziejach jako pismo propagujacce program radykalnych reform społecznych ${ }^{23}$.

Pierwsze lata XX w. na warszawskim rynku prasowym były również okresem nieznacznego złagodzenia cenzury, wzrostu czytelnictwa i nakładów. Do najbardziej poczytnych tygodników należały magazyny ilustrowane, w tym „Tygodnik Ilustrowany” i „Wędrowiec”, których łączny nakład w 1904 r. wynosił 23100 egzemplarzy ${ }^{24}$. Tego typu pisma czytywane były przez całe rodziny, przekazywano je też sąsiadom, co powodowało znaczny wzrost ich oddziaływania. Szacuje się, że pojedyncze egzemplarze trafiały do rąk nawet dziesięciu osób. W przypadku mniej popularnych rodzajów czasopism liczba czytelników jednego numeru była o połowę mniejsza ${ }^{25}$. Pozostałe $z$ wymienionych tygodników wydawano w nakładzie między 1000 a 2500 egzemplarzy. Wyjątkiem były czasopisma dla kobiet ${ }^{26}$. Najpopularniejsze w tym nurcie na terenie Królestwa Polskiego, czyli „Tygodnik Mód i Powieści” oraz „Bluszcz”, w 1904 r. łącznie wychodziły w liczbie 13400 egzemplarzy ${ }^{27}$. Różnice w nakładach poszczególnych typów pism jednoznacznie wskazują, że dla wizerunku ruchu kobiecego budowanego za pośrednictwem wymowy relacji na temat wydarzeń berlińskich kluczowe znaczenie miały tygodniki ilustrowane oraz tytuły przeznaczone dla kobiet.

\footnotetext{
${ }_{22}$ M. Brykalska, Aleksander Świętochowski. Biografia..., op. cit., s. 38-50.

23 A. Jaszczuk, op. cit., s. 221 i n; W. Giełżyński, op. cit., s. 369-370, 377-378.

24 Z. Kmiecik, Prasa warszawska..., op. cit., s. 21-24; Idem, Wydawnictwa periodyczne w Królestwie Polskim w latach 1868-1904, „Rocznik Historii Czasopiśmiennictwa Polskiego" 1965, t. 4, z. 2, s. 157; Idem, „Tygodnik Ilustrowany”..., op. cit., s. 25-42.

${ }^{25}$ Idem, Prasa warszawska..., op. cit., s. 24.

${ }^{26}$ Czasopisma dla kobiet nie stanowily kategorii o charakterze homogenicznym. Wchodziły do niej zarówno pisma prorodzinne, zachowawcze programowo, jak i tytuły o charakterze patronackim, zawodowym oraz pisma feministyczne (por. Z. Sokół, $Z$ badań nad polska prasa kobieca w latach 1818-1939, „Kwartalnik Historii Prasy Polskiej” 1983, t. 22, z. 3, s. 5-7; K. Orecka, Prasa dla kobiet jako odzwierciedlenie zmiany roli i pozycji kobiety $w$ dziewiętnastowiecznym społeczeństwie [w:] Przeszłość - Teraźniejszość - Przyszłość. Problemy badawcze młodych politologów, red. D. Mikucka-Wójtowicz, Kraków 2010, s. 23-35).

27 Z. Kmiecik, Wydawnictwa periodyczne..., op. cit., s. 155-159.
} 


\section{Konteksty - autorki i autorzy tekstów}

Przełom XIX i XX w. to także wzrost liczby osób zajmujących się dziennikarstwem. Redakcje warszawskie nie zatrudniały jednak wielu stałych pracowników i zabiegały o współpracę z literatami, działaczami i innymi przedstawicielami inteligencji, którzy zresztą zainteresowani byli tego typu aktywnościa jako dodatkowym źródłem utrzymania. Wokół czasopism społeczno-kulturalnych zbierał się więc zwykle krag publicystów-ideologów, literatów, uczonych czy popularyzatorów, w tym wybitnych przedstawicieli świata nauki i kultury, niekiedy nawet prezentujacych odmienne od linii pisma stanowiska światopoglądowe ${ }^{28}$.

W tym gronie były także kobiety, którym drogę do pracy dziennikarskiej torowała zwykle działalność społeczna lub literacka. Tak też było w przypadku autorek sprawozdań i komentarzy dotyczących wydarzeń berlińskich. W znakomitej większości wyszły one bowiem spod pióra polskich działaczek społecznych i feministycznych, zwykle zwiazanych już wcześniej z danym tytułem. I tak: w „Tygodniku Ilustrowanym” znajdziemy tekst Julii Kisielewskiej29, w pismach skierowanych do kobiet pojawiły się zaś artykuły Teodory Męczkowskiej ${ }^{30}$ - na łamach „Tygodnika Mód i Powieści” oraz Eugenii Żmijewskiej ${ }^{31}$ - w „Bluszczu”. Postępowe i rady-

${ }_{28}$ M. Kwiatkowska, Udział redakcji warszawskich czasopism kulturalno-społecznych $w$ rozpowszechnianiu ksiażki naukowej $w$ drugiej połowie XIX i na poczatku XX wieku, „Acta Universitatis Lodziensis. Folia Librorum” 2005, t. 12, s. 5-33.

${ }_{29}$ Julia Kisielewska (1874-1943) - pisarka, publicystka, tłumaczka, działaczka oświatowa, krytyk literacki. Pisała pod pseudonimem Julia Oksza. W 1904 r. współpracowała z „Tygodnikiem Ilustrowanym” i „Ogniwem”. Od 1906 r. redagowała „Swiat Kobiecy” (T. Jałmużna, Julia Kisielewska - nauczycielka i wychowawczyni [w:] Historia, społeczeństwo, wychowanie. Ksiega pamiątkowa dedykowana Profesorowi Józefowi Miasso, red. K. Bartnicka [et al.], Pułtusk-Warszawa 2004, s. 241-245).

30 Teodora Męczkowska (1870-1954) - postępowa działaczka oświatowa związana w tym czasie $z$ radykalną (demokratyczna) inteligencją warszawską. W omawianym okresie publikowała na łamach "Ogniwa” artykuły na temat walki $z$ prostytucja i wraz P. Kuczalska-Reinschmit redagowała rubrykę „Sprawy kobiece”. Późniejsza autorka prac na temat ideałów etyczno-społecznych ruchu kobiecego i koedukacji, zwolenniczka ruchu eugenicznego (M. Lipska, R. Loth, op. cit., s. 98-99).

31 Eugenia Żmijewska (1865-1923) - publicystka, pisarka, tłumaczka. Zwiazana z prasa konserwatywną. Prowadziła dział wiadomości zagranicznych w „Słowie”. W latach 1900-1906 publikowała w dodatku „Ognisko” do „Kuriera Polskiego”. Współpracowała z „Bluszczem”, później prowadziła pismo „Swiat Kobiecy” (S. Dziki, Eugenia Żmijewska (1865-1923). Materiały do słownika dziennikarzy i publicystów polskich, „Zeszyty Prasoznawcze” 1965, R. 6, nr 3 (25), s. 64). 
kalne tygodniki również zamieściły teksty: Eugenii Sokolnickiej ${ }^{32}$ („Prawda”), Róży Centnerszwerowej ${ }^{33}$ („Niwa Polska”), Pauliny Kuczalskiej-Reinschmit ${ }^{34}$ („Ogniwo”) i Izabeli Moszczeńskiej35 („Głos”). Poza „Wędrowcem”, który opublikował anonimowy krótki artykuł na temat Kongresu Kobiet (chociaż jako jedyny opatrzony zdjęciami najbardziej znanych działaczek obecnych w Berlinie), tylko „Przegląd Tygodniowy” i „Kraj” przyjęły do druku teksty napisane przez mężczyzn, w obu przypadkach studentów będacych dopiero na początku swojej kariery publicystycznej. Odpowiednio byli to: Stanisław Kelles-Krauz (1863-1965), wówczas student medycyny w Wiedniu, młodszy brat Kazimierza Kellesa-Krauzego i podobnie jak on związany ze środowiskiem PPS, od 1902 r. publikujący w krakowskim feministycznym „Nowym Słowie” Marii Turzymy ${ }^{36}$, oraz Józef Wasowski, właściwie Wassercug (1885-1947), zgłębiający w tym czasie nauki społeczne w Paryżu, mający już w swoim dorobku publikacje na łamach „Ogniwa” pod pseudonimem Widz ${ }^{37}$.

To zestawienie autorek i autorów relacji wskazuje, że nie były to osoby przypadkowe. $\mathrm{W}$ gronie tym nie brakuje bowiem działaczek zaangażowanych w tzw. kwestię kobieca, chociaż różniących się perspektywa programowa, w jakiej ją umieszczały (liberalna/postępowa,

\footnotetext{
32 Eugenia Sokolnicka (1876-1934) - późniejsza słynna psychoanalityczka, współtwórczyni francuskiego ruchu psychoanalitycznego. Zwiąana była w tym czasie ze środowiskiem PPS (P. Dybel, Eugenia Sokolnicka, Internetowy Słownik Biograficzny [online], [Dostęp: 30.01.2018]. Dostępny w World Wide Web: <http://bit.ly/2KyPG2b>).

33 Róża Centnerszwerowa (1865-1940) - postępowa działaczka oświatowa, popularyzatorka koedukacji, tłumaczka. Publikowała w „Ogniwie” w latach 1903-1905. Współpracowała także z pismem „Izraelita” (Z. Kołodziejska, „Izraelita”(1866-1915). Znaczenie kulturowe i literackie czasopisma, Kraków 2014, s. 93-94).

34 Paulina Kuczalska-Reinschmit (1859-1921) - wiodąca postać polskiego ruchu feministycznego przełomu XIX i XX stulecia. W omawianym okresie współpracowała nie tylko $z$ „Ogniwem”, lecz także $z$ „Tygodnikiem Mód i Powieści”. Jej działalność ma już rozległa literaturę przedmiotu. $Z$ ostatnich zob. A. Zawiszewska, Aktivitätsmodelle der deutschen Frauenbewegung um die Wende vom 19. zum 20. Jahrhundert in Gesellschafticher und Publizistischer Tätigkeit von Paulina Kuczalska-Reinschmit, „Colloquia Germanica Stetinensia" 2016, nr 25, s. 101-120.

35 Izabela Moszczeńska (1864-1841) - była zwolenniczką liberalno-narodowego podejścia do emancypacji kobiet i przeciwniczka politycznego feminizmu reprezentowanego przez P. Kuczalska-Reinschmit (R. Blobaum, op. cit., s. 40-41, 49-50).

36 Do Marii Kelles-Krauzowej w Wiedniu, 17.11.1902 [w:] K. Kelles-Krauz, Listy, t. 2: 1898-1905, red. F. Tych, Wrocław 1984, s. 654. Zob. też: K. Sierakowska, „Nowe Słowo" - trybuna emancypantek polskich [w:] Działaczki społeczne, feministki, obywatelki..., op. cit., s. 69-79.

37 D. Nałęcz, Życiorys konsekwentny (Józef Wasowski), „Kwartalnik Historii Prasy Polskiej" 1992, t. 31, z. 3/4, s. 203-208; M. Lipska, R. Loth, op. cit., s. 163-164.
} 
socjalistyczna i feministyczna). Można więc oczekiwać, iż ich narracje nie będą dyskredytowały ruchu kobiecego, podobnie jak teksty piszacego na temat wydarzeń berlińskich socjalisty Stanisława Kellesa-Krauzego i wolnomyśliciela Józefa Wassercuga. Pewności takiej nie ma już jednak w przypadku Eugenii Żmijewskiej, która powiazana była $z$ „zachowawcami" i krytykowała wszelkie skrajne programy feministyczne, stojacc na stanowisku, że kobieta powinna jedynie uzupełniać mężczyznęę

\section{Konteksty - okoliczności berlińskiego zjazdu kobiet}

Jak już wyżej wspomniano, berliński zjazd działaczek ruchu kobiecego w 1904 r. wiązał się z działalnością Międzynarodowej Rady Kobiet (ICW). Organizacja ta powstała w Waszyngtonie w 1888 r. podczas drugiej międzynarodowej konferencji zorganizowanej przez Narodowe Stowarzyszenie Praw Wyborczych Kobiet (National Woman Suffrage Association, NWSA) i odbywającej się w ramach obchodów czterdziestolecia słynnej konwencji w Seneca Falls z 1848 r. Inicjatorkami przedsięwzięcia były Elizabeth Cady Stanton (1815-1902) i Susan B. Anthony (18201906), które po kilkuletnich przygotowaniach i konsultacjach zaprosiły do Waszyngtonu przedstawicielki różnych pod względem programowym stowarzyszeń z myślą o stworzeniu ram organizacyjnych międzynarodowego ruchu kobiecego ${ }^{39}$. Powołana wówczas Międzynarodowa Rada Kobiet zintegrowała działaczki, które w różnych krajach prowadziły podobną aktywność. Nawiązanie współpracy i zbudowanie sieci powiązań służyło wymianie doświadczeń oraz prowadziło do efektywnego włączania się stowarzyszeń kobiecych w podejmowane w tym czasie reformy społeczne zmierzające do poprawy warunków życia w industrializujących się miastach. Założycielki były przekonane, że zorganizowany ruch kobiecy może w szczególny sposób wspierać rodziny i tym samym pozytywnie wpływać na transformacje społeczne w poszczególnych państwach.

Ten umiarkowany program, jak również podkreślane w statucie apolityczność i indyferentyzm religijny ICW miały sprzyjać współdziała-

\footnotetext{
38 Z. Anculewicz, Świat i ziemie polskie w oczach redaktorów i współpracowników „Kuriera Warszawskiego" w latach 1868-1915, Warszawa 2002, s. 552.

39 L.J. Rupp, Worlds of Women. The Making of an International Women's Movement, Princeton 1997, s. 15; A.S. Fell, I. Sharp, Introduction: The Women's Movement and the First World War [w:] The Women's Movement in Wartime. International Perspectives, 1914-19, red. A.S. Fell, I. Sharp, Basingstoke 2007, s. 9-10.
} 
niu możliwie jak największej liczby stowarzyszeń oraz zapobiec ewentualnym sporom na tle ideowym. W skład Międzynarodowej Rady Kobiet jako organizacji dachowej wchodziły narodowe organizacje kobiece, czyli zrzeszenia stowarzyszeń działających w danym kraju. W Stanach Zjednoczonych tego typu organizacja narodowa została powołana już podczas waszyngtońskiego zjazdu w 1888 r. (National Council of Women of the United States, NCW/US). Kilka lat później, bo w 1894 r., podobną założono również w Niemczech - przyjęła ona nazwę Związku Niemieckich Stowarzyszeń Kobiecych (Bund Deutscher Frauenvereine, BDF) i w 1897 r. weszła w skład ICW ${ }^{40}$.

Statut Międzynarodowej Rady Kobiet gwarantował swoim organizacjom członkowskim pełną samodzielność wewnętrzna. Ich delegatki spotykały się co pięć lat na specjalnych zgromadzeniach generalnych zwoływanych w państwach poszczególnych organizacji narodowych należących do Rady. W czasie zgromadzeń wybierano przewodniczącą oraz Komitet Wykonawczy, którego ciałem doradczym miało być gremium złożone $z$ przewodniczących poszczególnych związków narodowych ${ }^{41}$. Zgromadzeniom generalnym towarzyszyły międzynarodowe kongresy kobiet, co było nawiązaniem do zjazdów zapoczątkowanych w 1878 r. przez Międzynarodowy Kongres Praw Kobiet (Congrès international de droit des femmes) - pierwszy miał miejsce w Paryżu w ramach odbywajaccej się tam wówczas światowej wystawy przemysłowej. Pierwsze zgromadzenie generalne Międzynarodowej Rady Kobiet wraz z kongresem kobiet odbyły się w Chicago w maju 1893 r., również w czasie trwającej w tym mieście światowej wystawy przemysłowej. Drugie miało natomiast miejsce na przełomie czerwca i lipca 1899 r. w Londynie ${ }^{42}$. Wówczas to ujawniły się

${ }^{40}$ U. Gerhard, National oder International. Die internationalen Beziehungen der deutschen bürgerlichen Frauenbewegung, „Feministische Studien” 1994, H. 2, s. 36-37. Poza BDF do 1904 r. członkami ICW zostały narodowe zrzeszenia organizacji kobiecych z Kanady (1893), Wielkiej Brytanii (1898), Szwecji (1898), Australii (1899), Danii (1899), Holandii (1899), Włoch (1900), Nowej Zelandii (1900), Argentyny (1901), Francji (1901), Austrii (1903), Szwajcarii (1903), Węgier (1904) i Norwegii (1904; zob. L.J. Rupp, op. cit., s. 16). ${ }^{41}$ Przewodniczące wybierane były na pięcioletnie kadencje. Pierwszą $\mathrm{z}$ nich w $1888 \mathrm{r}$. została angielska działaczka Millicent Fawcett, druga w 1893 r. Lady Aberdeen (Ishbel Maria Hamilton-Gordon, markiza Aberdeen i Temair), trzecią zaś w 1899 r. Amerykanka May Wright Sewall.

42 A. Schüler, K. Wolff, „Es sind die gleichen Überzeugungen, die die Frauen aller Länder erfüllen..." Zur Entstehung von internationalen Netzwerken in den Frauenbewegung [w:] Politische Netzwerkerinnen. Internationale Zusammenarbeit von Frauen 1830-1960, red. E. Schöck-Quinteros, A. Schüler, A. Wilmers, K. Wolff, Berlin 2017, s. 20. Zob. też: Ch. Kersting, Weibliche Bildung und Bildungspolitik das International Council of Women 
pierwsze rozdźwięki w ICW na tle stosunku do praw wyborczych kobiet, które zaowocowały koncepcja powołania odrębnej międzynarodowej organizacji zrzeszającej wyłącznie sufrażystki. Plan ten był wyrazem rozczarowania stanowiskiem Międzynarodowej Rady Kobiet, która zgodnie ze swoim umiarkowanym programem unikała poparcia tego postulatu. Pomysł nabrał konkretnych kształtów w 1902 r. w Waszyngtonie. Miała tam wówczas miejsce międzynarodowa konferencja zwolenniczek praw wyborczych dla kobiet (First Conference of the International Woman Suffrage Alliance) zainicjowana przez powstała w 1890 r. organizację dachowa skupiajaca amerykańskie stowarzyszenia sufrażystek (National American Woman Suffrage Association, NAWSA), na która zaproszono działaczki $z$ innych krajów. Wśród przybyłych znajdowały się również przedstawicielki powstałego na początku 1902 r. Niemieckiego Stowarzyszenia na Rzecz Praw Wyborczych Kobiet (Deutscher Verein für Frauenstimmrecht, DVF) z Anitą Augspurg (1857-1943) i Lidą Gustava Heymann (1868-1943) na czele, które wcześniej były aktywne na forum ICW. Skutkiem wspólnych obrad była decyzja o powołaniu nowej międzynarodowej organizacji skupiajacej wyłącznie zwolenniczki praw wyborczych. Jej oficjalne powołanie i przyjęcie statutu miało nastapić podczas specjalnego kongresu w Berlinie przygotowanego przez DVF ${ }^{43}$. Zgodnie $z$ decyzjami, jakie zapadły w Londynie podczas zebrania ścisłego kierownictwa Międzynarodowej Rady Kobiet w 1897 r., Berlin także miał być gospodarzem kolejnego po londyńskim zgromadzenia generalnego ICW i Kongresu Kobiet. Do stolicy Niemiec działaczki zostały zaproszone przez Zwiazek Niemieckich Stowarzyszeń Kobiecych. Mimo że wkrótce Międzynarodowa Rada Kobiet podważyła celowość zwoływania kongresów jako wydarzeń towarzyszących jej obradom, działaczki niemieckie trwały w swoim postanowieniu, decydujac się na samodzielne ( $\mathrm{tj}$. bez wsparcia ICW) przygotowanie zaplanowanego kongresu ${ }^{44}$, zwłaszcza że miały już pewne doświadczenie w tej dziedzinie ${ }^{45}$.

und seine Kongresse in Chicago (1893), London (1899) und Berlin (1904), „Paedagogica Historica" 2008, Vol. 44, No. 3, s. 327-346.

43 S. Kinnebrock, „Wahrhaft international?" Soziale Bewegungen zwischen nationalen Öffentlichkeiten und internationalem Bewegungsverband [w:] Politische Netzwerkerinnen..., op. cit., s. 42-43.

${ }_{44}$ M. Stritt, Eröffnungsansprache [w:] Eadem, Der Internationale Frauen-Kongress in Berlin 1904. Bericht mit ausgewählten Referaten, Berlin 1905, s. 1.

45 Kilka lat wcześniej, w 1896 r. odbył się już w Berlinie międzynarodowy kongres kobiet. Nie miał on jednak nic wspólnego z działalnością Międzynarodowej Rady Kobiet. Kongresy 
W ten sposób Berlin w 1904 r. miał się stać widownią dwóch konkurencyjnych wydarzeń - Międzynarodowego Kongresu Kobiet organizowanego przez BDF (silne zrzeszenie integrujace, umiarkowane pod względem programowym skrzydło mieszczańskiego ruchu kobiecego) oraz kongresu sufrażystek przygotowywanego przez DVF (słabe stowarzyszenie współtworzące, dopiero się organizujące radykalne skrzydło mieszczańskiego ruchu kobiecego w Niemczech). Kiedy się okazało, że kongres zwolenniczek praw wyborczych ma się odbyć na początku czerwca 1904 r., tj. tuż przed zgromadzeniem generalnym ICW i kongresem przygotowywanym przez BDF, organizujące je działaczki niemieckie poczuły się bardzo zaniepokojone. Obawiały się, że zjazd sufrażystek skupi na sobie całą uwagę prasy i opinii publicznej, która później nie dostrzeże przygotowanych przez nie wydarzeń. Helene Lange (1848-1930) i Marie Stritt (1855-1928), przedstawicielki BDF w Międzynarodowej Radzie Kobiet, zaczęły więc naciskać na May Wright Sewall, jej ówczesna przewodnicząca, by nie dopuściła do takiej sytuacji. Jedynym, co udało się wynegocjować $z$ organizatorkami planowanego kongresu sufrażystek, była deklaracja $z$ ich strony, iż przygotowywany przez nie zjazd będzie miał charakter prywatnej konferencji i tym samym nie zafunkcjonuje w przestrzeni publicznej Berlina. Zwolenniczkom praw wyborczych kobiet zależało bowiem na połączeniu w czasie obu wydarzeń, gdyż widziały w tym możliwość rozszerzenia swojego oddziaływania i szansę na przystapienie do ruchu sufrażystowskiego kobiet przybyłych na konkurencyjny kongres ${ }^{46}$. W tych okolicznościach w 1904 r. w Berlinie odbyły się kolejno: 3 i 4 czerwca konferencja sufrażystek (Second Conference of the International Woman Suffrage Alliance) zorganizowana przez Niemieckie Stowarzyszenie na Rzecz Praw Wyborczych, podczas której utworzony został Międzynarodowy Sojusz na Rzecz Praw Wyborczych Kobiet, następnie w dniach 6-11 czerwca zgromadzenie generalne Międzynarodowej Rady Kobiet, między 13 a 17 czerwca zaś obrady Międzynarodowego

różnych organizacji były bowiem w tym czasie bardzo modne. Często towarzyszyły im też popularne wówczas wystawy różnego typu wytwórczości, np. pracy kobiet (M. Lischnewska, Der internationale Frauenkongreßs in Berlin vom 19. bis 26. September 1896 [w:] Die Lehrerin in Schule und Haus. Centralorgan für die Interessen der Lehrerinnen und Erzieherinnen im In- und Auslande, red. M. Loeper-Housselle (30 Jg, 1896-1897), Gera-Leipzig 1897, s. 99-106).

46 S. Kinnebrock, op. cit., s. 45. 
Kongresu Kobiet przygotowanego przez Niemiecki Związek Stowarzyszeń Kobiecych.

Niemiecka prasa, niezależnie od opcji politycznej, dużo uwagi poświęciła tym wydarzeniom, również konferencji sufrażystek, mimo iż miała mieć ona charakter prywatny. Jak się jednak okazało - o czym napisała w swojej relacji dla „Ogniwa” Paulina Kuczalska-Reinschmit zaproszono na nią dziennikarzy, a po zakończeniu obrad zorganizowano publiczna sesję $z$ pięcioma referatami na temat praw wyborczych dla kobiet, którym miało się przysłuchiwać blisko 1,5 tys. osób ${ }^{47}$. Zainteresowaniu konferencja sprzyjała także obecność dwóch słynnych amerykańskich sufrażystek, Carrie Chapmann Catt (1859-1947), a zwłaszcza seniorki, 84-letniej Susan B. Anthony, z których pierwsza stanęła na czele powołanego w Berlinie sojuszu, druga zaś wybrana została jego honorowa przewodniczacą ${ }^{48}$.

\section{Charakter relacji}

W tygodnikach warszawskich informacje na temat wydarzeń berlińskich zamieszczane były głównie na przełomie czerwca i lipca $1904 \mathrm{r}$. Najobszerniejsza $z$ nich, stanowiąca cykl czterech artykułów, przygotowała Paulina Kuczalska-Reinschmit. Cykl ów miał charakter relacji bieżącej. Autorka przesyłała do redakcji „Ogniwa” omówienie każdego kolejnego wydarzenia, w którym uczestniczyła (pierwszy tekst ukazał się już w numerze z 11 czerwca) ${ }^{49}$, w przypadku Kongresu Kobiet także czynnie $^{50}$. Większość publikacji była jednak omówieniami ex post przygotowanymi - jak można wnosić na podstawie sposobu narracji - z pozycji uczestnika wydarzeń. Odmienny charakter przypisać można jedynie opublikowanemu późno, bo dopiero 23 lipca, artykułowi Róży Centnerszwerowej, która - co sugeruje wstępna część jej relacji - konferencję sufrażystek, zebranie generalne ICW oraz Międzynarodowy Kongres Kobiet

\footnotetext{
${ }_{47}$ PKR, Międzynarodowe zjazdy kobiet. II (Pogrom Berlina przez Amerykanki) Berlin 7 VI, "Ogniwo" 1904, nr 25, s. 594.

48 S. Kinnebrock, op. cit., s. 46-47.

49 P.K.R., Międzynarodowe zjazdy kobiet. I. Berlin 5 czerwca, „Ogniwo” 1904, nr 24, s. 568-570; Eadem, Międzynarodowe zjazdy kobiet. II..., op. cit., s. 594-595; Eadem, Międzynarodowe zjazdy kobiet, III. Berlin 12 czerwca, „Ogniwo” 1904, nr 26, s. 618-619; Eadem, Międzynarodowe zjazdy kobiet, IV. Berlin 19 czerwca 1904, „Ogniwo” 1904, nr 28, s. 667-669.

50 M. Stritt, Der Internationale Frauen-Kongress..., op. cit., s. 104, 157.
} 
przedstawiła i skomentowała na postawie sprawozdań korespondentów zamieszczanych w prasie codziennej ${ }^{51}$.

Omawiane relacje zdecydowanie różnią się między sobą głębia i zakresem przekazywanych informacji. Poza wspomnianymi wyżej tekstami Pauliny Kuczalskiej-Reinschmit i Róży Centnerszwerowej jedynie artykuł Stanisława Kellesa-Krauzego w „Przeglądzie Tygodniowym” zawiera odniesienie do wszystkich berlińskich wydarzeñ ${ }^{52}$. Inne teksty albo pomijają konferencję sufrażystek (Eugenia Żmijewska na łamach „Bluszczu”53), albo zgromadzenie generalne ICW (Eugenia Sokolnicka na łamach „Prawdy" ${ }^{54}$ ) bądź też oba te wydarzenia i koncentrują się wyłącznie na Kongresie Kobiet. Do tej ostatniej grupy należa relacje: Teodory Męczkowskiej dla „Tygodnika Mód i Powieści”55, Józefa Wassercuga dla „Kraju”56 i Julii Kisielewskiej dla „Tygodnika Ilustrowanego” (mimo iż w dziale tego tygodnika zatytułowanym „Ze świata kobiecego” zapowiadano i inne wydarzenia berlińskie ${ }^{57}$ ) oraz zamieszczony w „Wędrowcu” anonimowy tekst skupiajacy się na ukazaniu Kongresu przez pryzmat ciekawostek (np. udziału czarnoskórej działaczki ze Stanów Zjednoczonych czy pierwszej holenderskiej lekarki), ale jako wydarzenia o charakterze postępowym i demokratycznym ${ }^{58}$.

Kategorię tę zamyka relatywnie krótki tekst Izabeli Moszczeńskiej opublikowany w końcu czerwca na łamach „Głosu”. Moszczeńska nie potraktowała jednak Kongresu sprawozdawczo, nie ma u niej więc tak jak w innych artykułach relacji deskryptywnej. Publikację poświęciła przede wszystkim ocenie kondycji niemieckiego ruchu kobiecego, wykazując się zreszta doskonała orientacją w tej materii. Według niej Kongres, chociaż międzynarodowy, to jednak zdominowany został przez Niemki i był raczej odbiciem stanu feminizmu w Niemczech, niż na świecie. Moszczeńska

\footnotetext{
51 R. Cent..., Międzynarodowy zjazd kobiecy, „Niwa Polska” 1904, nr 30, s. 403-405.

52 S. Krauz, Kongres Kobiecy w Berlinie, „Przegląd Tygodniowy” 1904, nr 29, s. 346-347.

53 E. Żm., Trzeci międzynarodowy kongres kobiet, „Bluszcz” 1904, nr 24, s. 318-319.

54 Obszerna relacja E. Sokołowskiej z konferencji sufrażystek i kongresu kobiet ukazała się w dwóch kolejnych numerach „Prawdy” (E.S., Walka o prawo wyborcze i Kongres międzynarodowy kobiet, „Prawda” 1904, nr 27, s. 318-319; Eadem, Walka o prawo wyborcze i Kongres międzynarodowy kobiet (cd.), Ibidem, nr 28, s. 328-329).

55 T.M., Międzynarodowy kongres kobiet $w$ Berlinie, „Tygodnik Mód i Powieści” 1904, nr 31, s. 363.

56 Widz, Berlin, w czerwcu [Międzynarodowy kongres kobiecy], „Kraj” 1904, nr 24, s. 12.

57 J.O., Kongres międzynarodowy kobiecy w Berlinie, „Tygodnik Ilustrowany” 1904, nr 22,

s. 506; Ze świata kobiecego, Ibidem, nr 28, s. 559.

58 Kongres kobiecy w Berlinie, „Wędrowiec” 1904, nr 27, s. 13.
} 
zauważyła znaczną zmianę w społecznej recepcji ruchu kobiecego w tym kraju. Przestał być on tam uważany za śmieszny i $w$ złym guście, co więcej, stwierdziła, że grozi mu bycie modnym. Przesłanką do tego miało być zainteresowanie Kongresem ze strony cesarzowej Augusty Wiktorii, która zwykle nie angażowała się w podobne przedsięwzięcia. Tym razem jednak przyjęła na audiencji jego delegatki, co spowodowało, że problematyka kobieca trafiła na salony, stała się hoffähig. Według autorki sytuacja ta może się zakończyć tym, że wkrótce żony i córki dygnitarzy, oficerów i urzędników będą się zapisywać do stowarzyszeń, co jej zdaniem doprowadzi do paraliżu ich funkcjonowania ${ }^{59}$.

Moszczeńska zwróciła uwage na jeszcze jedną istotną sprawę, mianowicie cel, jaki postawiły sobie organizatorki: Niemki cały swój punkt honoru zasadzały na tem, by scen uniknać, rozdrażnienia nie dopuszczać, równowagi nie zachwiać i zamanifestować wobec świata kobieca dojrzałość $i$ kobiece umiarkowanie. W zwiazku z tym wszystkie sprawy, które mogły wywołać gwałtowne spory, zostały usunięte z porządku obrad, dyskusje zaś wyciszone. Tonowaniem przebiegu obrad działaczki chciały zneutralizować nieprzychylny i lekceważacy stosunek do zjazdów kobiecych, jaki się utrwalił w opinii publicznej za sprawą kongresu paryskiego z 1892 r. Tę dbałość o pozory, powage i unikanie wszystkiego, co mogłoby ośmieszyć ruch kobiecy, Moszczeńska uważa zreszta za cechy feminizmu ${ }^{60}$ niemieckiego. Ta skądinąd trafna ocena polityki miejscowych aktywistek była uwarunkowana sytuacją w Wilhelmińskiej Rzeszy, państwie $z$ głębokimi podziałami stanowymi i dużymi wpływami konserwatystów wykorzystujacych każdy powód do zdyskredytowania działaczek i ich postulatów ${ }^{61}$. Jak zauważa Moszczeńska, założony cel został osiagnięty, co zaowocowało przychylnością wyższych kręgów społecznych i pozytywnymi komentarzami prasy.

Relacja opublikowana w "Głosie”, mimo że pod względem charakteru odbiegała od innych zawierajacych znacznie więcej elementów sprawozdawczych, to jednak włącza się do grupy tych, które dają czytelnikowi wiele informacji także na temat dotychczasowej działalności Międzynarodowej Rady Kobiet, okoliczności organizacji zjazdu berlińskiego

\footnotetext{
59 M., Międzynarodowy kongres kobiecy $w$ Berlinie, „Głos” 1904, nr 28, s. 439-440.

60 Termin „feminizm” używany jest w relacjach $z$ kongresu jako synonim „kobiecy” i nie ma żadnych konotacji programowych.

${ }^{61}$ M., op. cit., s. 440.
} 
i sytuacji w niemieckim ruchu kobiecym. Doskonałe rozeznanie w tej problematyce poza Moszczeńska zaprezentowały autorki najobszerniejszych relacji, czyli Kuczalska-Reinschmit i Sokołowska, a oprócz nich również Centnerszwerowa i Kelles-Krauz. Oznacza to więc, że najrzetelniejsze wprowadzenie do wydarzeń berlińskich otrzymali czytelnicy tygodników skierowanych do postępowej i radykalnej inteligencji, a więc tytułów, które wspierały „kwestię kobieca”. Poparcie redakcji, jak i samych piszących dla programów emancypacyjnych (Moszczeńska - liberalnego, Kuczalska-Reischmit - feministycznego, Sokołowska, Centnerszwerowa i Kelles-Krauz - socjalistycznego) nie oznaczało jednak, że w tekstach bezkrytycznie się odnoszono do wydarzeń berlińskich. Niemniej należy podkreślić, iż negatywne komentarze dotyczące zwłaszcza organizacji i programu obrad kierowane były tylko pod adresem Kongresu Kobiet. Inne wydarzenia berlińskie spotkały się z pozytywnym przyjęciem, szczególnie powołanie Międzynarodowego Sojuszu na Rzecz Praw Wyborczych Kobiet, które dla Sokołowskiej i Centnerszwerowej było najdonioślejszym rezultatem czerwcowego zjazdu działaczek.

Poza wymienionymi wyżej autorkami krytycznie o Kongresie Kobiet pisały Kisielewska i Męczkowska. Zastrzeżenia wzbudzały przede wszystkim zbyt duża liczba referatów i zbyt szeroka ich rozpiętość tematyczna powodujacca w efekcie chaos informacyjny. Nie podobało im się również odcięcie od Kongresu Kobiet środowiska robotniczego. W warunkach niemieckich posunięcie to było jednak naturalna koniecznościa wynikająca $z$ rywalizacji między mieszczańskim ruchem kobiecym (reprezentowanym przez BDF) a socjaldemokratycznym (mającym duże wpływy w klasie pracującej). Męczkowska była zresztą przeciwna kongresom jako formie nawiązania współpracy międzynarodowej wśród kobiet. Uważała, że lepszym rozwiąaniem byłaby wymiana myśli za pośrednictwem czasopism. Kongresy były według niej jedynie sposobnościa do zaspokojenia próżności i prezentowania swoich popisów retorycznych ${ }^{62}$. Jej relacja opublikowana na łamach „Tygodnika Mód i Powieści”, dość wyraźne nasycona wartościującymi negatywnie ocenami, różni się zdecydowanie od relacji opublikowanej w drugim piśmie dla kobiet, tj. „Bluszczu”. Jego autorka Eugenia Żmijewska raczej unika ocen, starając się w tonie neutralnym ukazać przebieg Kongresu. Konwencja nawiazuje jednak miejscami do tekstu opublikowanego w „Wędrowcu”. Wyławia

62 T.M., op. cit., s. 363.

Czasopismo Naukowe Instytutu Studiów Kobiecych 
bowiem ciekawostki, przykuwające uwagę szczegóły. Informuje m.in. o referacie na temat życia kobiet w tureckich haremach czy też o pomyśle jednorocznej obowiązkowej służby dziewcząt w szpitalach mającej być odpowiednikiem służby wojskowej mężczyzn ${ }^{63}$.

$Z$ kolei pozytywne oceny, zwłaszcza formułowane nie tyle wobec Kongresu, ile samego ruchu kobiecego i jego rozwoju na przełomie wieków, dominują w relacji opublikowanej na łamach konserwatywnego „Kraju”. Józef Wassercug nie relacjonuje zresztą przebiegu obrad. Narracja deskryptywna została zastapiona tu przez narrację oceniająco-przekonująca, a więc taką, która ma wpłynać na odbiorcę (z założenia konserwatystę), a dokładniej na jego stosunek (z założenia negatywny) do emancypacji kobiet. Według autora Kongres berliński pokazał, że ruch kobiecy przestał być sportem wykolejonych emancypantek, które swe wyrzekania formułowały $w$ patetycznej skardze na podstępna chytrość rodu męskiego. Tym, co miało świadczyć o przemianie, osiagnięciu dojrzałości przez ruch, było odejście od kwestii zwiąanych $z$ równouprawnieniem politycznym kobiet i zajęcie się kwestiami społecznymi, ściśle powiązanymi z życiem codziennym ${ }^{64}$. Wassercug więc albo dał się zwieść organizatorkom Kongresu, albo wykorzystał stosowana przez nie taktykę do własnych celów, czyli nadania „nowej twarzy” emancypacji kobiet, łatwiejszej do oswojenia przez kręgi konserwatywno-zachowawcze. Jak wiadomo, działaczki niemieckie celowo wyciszyły kwestie sporne i zepchnęły na dalszy plan postulaty polityczne, by w ten sposób stać się dla konserwatywnych elit poważnym partnerem przy negocjowaniu realizacji proponowanych reform społecznych.

\section{Przebieg wydarzeń berlińskich}

Komplet informacji na temat tego, co się działo Berlinie w czerwcu 1904 r. wokół tzw. kwestii kobiecej, otrzymali tylko czytelnicy „Ogniwa”, „Przeglądu Tygodniowego” i „Niwy Polskiej”. Autorka, która w swoich relacjach zawarła najwięcej szczegółów, tak organizacyjnych, jak i programowych, okraszajac je wieloma ciekawostkami i fachowymi komentarzami, była - jak już wyżej wspomniano - Paulina Kuczalska-Reinschmit. Artykuły Stanisława Kellesa-Krauzego oraz Róży Centnerszwerowej nie

63 E. Żm., op. cit., s. 318-319.

$64 \mathrm{Widz}$, op. cit., s. 12. 
wniosły nic nowego do zaprezentowanego przez nia obrazu kolejnych wydarzeń. Szereg uzupełnień wyłowić można natomiast w relacji Eugenii Sokolnickiej zamieszczonej na łamach „Prawdy”, która z pozycji świadka pisała o konferencji sufrażystek i Kongresie Kobiet, nie odnosząc się jednak do zgromadzenia generalnego ICW.

Konferencja zwolenniczek praw wyborczych dla kobiet odbyła się 3-4 czerwca - jak podaje Kuczalska-Reinschmit - w sali balowej jednego $z$ najbardziej ekskluzywnych berlinskich hoteli, tj. Hotelu Prinz Albrecht. Zgromadziła wiele uczestniczek, które według niej nie wpisywały się w stereotyp sufrażystki. Na sali nie było bowiem wattych i chudych kobiet. Gros uczestniczek wyróżniało się natomiast tzw. strojem reformowanym, czyli pozbawionym gorsetu. Konferencję zdominowały Amerykanki. Wielkie uznanie budziła seniorka ruchu, najbardziej znana wówczas sufrażystka, 84-letnia Susan B. Anthony z Filadelfii, która w prywatnej rozmowie $z$ Kuczalska-Reinschmit dopytywała się o rodzinę swojej dawnej współpracowniczki, urodzonej w Piotrkowie Trybunalskim Ernestyny Rose (1810-1892). Na łamach „Ogniwa” czytelnicy oprócz przebiegu konferencji mogli również poznać opinię autorki na temat niemieckich działaczek ruchu na rzecz praw wyborczych, tj. łagodzacej spory dr Anicie Augspurg, niezmordowanej tłumaczce angielskich przemówien dr Käthe Schirmacher czy też dbającej o wyciszanie dyskusji wśród słuchaczek Minny Cauer.

Inne elementy tego wydarzenia eksponowała zaś Eugenia Sokolnicka. Dla niej konferencja dotyczyła nie tyle praw politycznych dla kobiet, ile szerzenia idei równouprawnienia. Za celowe uznała przytoczenie dyskusji na temat jednego $z$ punktów programu powoływanej do życia organizacji, mimo że ostatecznie został on wykreślony jako zbyt radykalny. Dotyczył on bowiem relacji między obu płciami, które według proponowanych zapisów miały się opierać na zasadzie równości zawierającej się w stwierdzeniu, iż kobieta winna jest posłuszeństwo mężczyźnie w takim samym stopniu, jak mężczyzna kobiecie. Ten swój punkt widzenia umocniła poprzez odwołania do opinii prasy na temat konferencji. Przytoczyła opinię zamieszczoną we „Frankfurter Zeitung”, z której wynika, że równouprawnienie polityczne obu płci jest walką $z$ niesprawiedliwościa, jaka dotyka inteligentne i wykształcone kobiety, które nie maja prawa 
głosu w sytuacji, gdy każdy parobek, majacy nader ograniczony horyzont myślowy, bierze udział $w$ życiu politycznym państwa ${ }^{65}$.

Kulminacyjnym momentem konferencji, wyeksponowanym przez obie autorki, było powołanie Międzynarodowego Sojuszu na Rzecz Praw Wyborczych Kobiet, który stojąc na stanowisku równości obu płci, miał działać na rzecz nadania im takich samych praw politycznych w państwach o ustroju konstytucyjnym. Na czele organizacji stanał zarząd wybierany na pięcioletnia kadencję. Jego honorową przewodnicząca została Susan B. Anthony ${ }^{66}$, rzeczywistą zaś Carrie Chapmann Catt, a zastępczyniami Anita Augspurg z Niemiec i Millicent Fawcett (1847-1929) z Wielkiej Brytanii. Do organizacji przystapiły stowarzyszenia walczące o prawa wyborcze działające w Niemczech, Wielkiej Brytanii, Holandii, Norwegii, Szwecji i Stanach Zjednoczonych oraz działaczki z Austrii, Węgier i Szwajcarii, które zobowiązały się doprowadzić w najbliższym czasie do powołania w swoich krajach odpowiednich zrzeszeń.

$Z$ relacji Kuczalskiej-Reinschmit wynika, że konferencja sufrażystek wbrew założeniom nie miała charakteru prywatnego. W sali obrad znajdował się bowiem stolik dla prasy, po zakończeniu obrad zaś organizatorki urządziły publiczne niebiletowane zebranie, podczas którego w wypełnionej po brzegi sali wygłoszono pięć referatów związanych $z$ kwestia praw wyborczych kobiet. Kuczalska-Reinschmit poświęciła mu osobną relację, która stała się dla niej pretekstem do tego, by skomentować walkę o prawa wyborcze kobiet jako konieczność wynikająca $z$ postępu cywilizacyjnego, potrzebe kulturalna, której realizacja nada lepszy, nowy kształt ludzkości ${ }^{67}$.

Kolejnym wydarzeniem związanym ze zjazdem kobiet było zgromadzenie generalne Międzynarodowej Rady Kobiet, które miało miejsce 8-9 czerwca w sali Beethovena berlińskiej filharmonii. W swoich artykułach wspominali o nim Kelles-Krauz i Centnerszwerowa oraz bardzo zdawkowo Żmijewska, najszerzej zaś Kuczalska-Reinschmit. W innych relacjach co prawda wypływały nawiazania do działalności ICW, ale tyl-

\footnotetext{
65 E.S., Walka o prawo wyborcze..., op. cit., s. 318.

66 Według Pauliny Kuczalskiej-Reinschmit Susan B. Anthony poprosiła, by tym zaszczytem obdarzyć także jej siostrę Mary, argumentując swój wniosek udziałem tej ostatniej w słynnej konferencji w Seneca Falls w 1848 r. Przypomniała, że to właśnie Mary podpisała za nią Deklarację Uczuć z 1848 r., gdyż ona jako nauczycielka nie mogła tego zrobić. Uczestniczki konferencji przystały na propozycję seniorki sufrażystek (P.K.R., Międzynarodowe zjazdy kobiet. I..., op. cit., s. 570).

67 Eadem, Międzynarodowe zjazdy kobiet. II..., op. cit., s. 594-595.
} 
ko w kontekście Kongresu Kobiet. W zgromadzeniu generalnym wzięły udział delegatki 19 związków narodowych wchodzących w skład Rady, które - jak podkreślono w prasie - reprezentowały 7 mln członkiń i członków. Jednym $z$ głównych punktów obrad były wybory nowego zarządu. Dotychczasowa przewodnicząca May Wright Sewall, wybraną w Chicago, zastapiła piastująca już wcześniej tę funkcję Angielka Lady Aberdeen. Jej zastępczyniami zostały: Niemka, przewodnicząca BDF Marie Stritt, Szwedka Anna Hierta-Retzius i Francuzka pani Siegfried (mylnie odnotowana przez Kuczalska-Reinschmit jako Simon). Następne zgromadzenie generalne miało się odbyć w 1909 r. w Kanadzie.

Szerzej o przebiegu zgromadzenia generalnego zostali poinformowani tylko czytelnicy „Ogniwa”. $Z$ zamieszczonej na jego łamach relacji wiadomo, że podczas dwudniowych obrad m.in. wysłuchano referatów ukazujących specyfikę działalności podejmowanej przez ruch kobiecy w poszczególnych krajach. Na kwestię tę zwróciła także uwagę w powitalnym przemówieniu May Wright Sewall, która podkreśliła, że działaczki musza się wznieść ponad partykularyzmy i pracować wspólnie w imię tych samych ideałów, bez względu na podziały społeczne. Kierunek najbliższych działań ICW wyznaczyły uchwały przegłosowane w Berlinie. Mianowicie na wniosek działaczek norweskich i francuskich Międzynarodowa Rada Kobiet zobowiązała się zwalczać handel kobietami i dążyć do zniesienia przepisów reglamentujących prostytucję w tych krajach, w których obowiazywały. Posunięcie to było również obliczone na wsparcie walki $z$ innymi standardami moralnymi obowiązujaccymi kobiety i mężczyzn. Natomiast na wniosek działaczek angielskich w tych państwach, gdzie rzą ma charakter reprezentacyjny, ICW miała wspomagać działania na rzecz uzyskania przez kobiety praw wyborczych.

Zgromadzenie generalne, chociaż miało charakter zamknięty, zakończyło się kilkoma zebraniami publicznymi, z których ostatnie poświęcone zostało kwestii utrzymania pokoju. Jedna $z$ referentek była Bertha von Suttner (1843-1914), już wówczas znana austriacka pacyfistka, której mowa wypowiedziana $z$ siła $i w$ artystycznej formie wywarła duże wrażenie na słuchaczach ${ }^{68}$.

Ostatnim $z$ wydarzeń berlińskich był Międzynarodowy Kongres Kobiet odbywający się w dniach 13-18 czerwca w zaadoptowanych na ten cel salach filharmonii (podobnie jak zgromadzenie generalne ICW).

68 Eadem, Międzynarodowe zjazdy kobiet. III..., op. cit., s. 618-619. 
Niemiecki komitet organizacyjny, dążąc do nadania niezwykłej oprawy temu wydarzeniu, zdecydował się na przystrojenie sal i korytarzy gmachu girlandami i kwiatami, jak również zaaranżowanie w nim przytulnych gabinetów za sprawą wypożyczonych od mieszkanek Berlina mebli i dywanów. Co prawda udekorowana w ten sposób filharmonia wzbudzała zachwyt, $z$ drugiej jednak strony przepych towarzyszacy kongresowi ściagnał na Niemiecki Związek Stowarzyszeń Kobiecych falę krytyki. Sokolnicka na łamach „Prawdy” pytała: Czyżby poważne obrady nad bytem samodzielnym $i$ stanowiskiem społecznym kobiety wymagały tych wszystkich aksesoryj?69

Podczas Kongresu zaplanowano cztery sesje tematyczne, które odbywały się równolegle. Każda $z$ nich poświęcona była określonej tematyce. Pierwsza $z$ nich, szczegółowo zreferowana przez Stanisława Kellesa-Krauzego, który - jak można wnosić $z$ charakteru jego relacji - uczestniczył w jej obradach, poświęcona została kwestii wychowania i kształcenia dziewczat. Druga pracy zarobkowej kobiet, trzecia natomiast kwestiom społecznym, takim jak opieka nad chorymi, dziećmi i matkami. Czwarta sesję poświęcono pozycji prawnej i politycznej kobiet. Obrady sekcji były otwarte dla publiczności, $z$ tym że uczestnictwo $w$ ich pracach wiazało się z koniecznością wykupienia - jak oceniano - dość drogiego biletu. W sumie - jak można przeczytać u Kuczalskiej-Reinschmit - podczas trzydziestu posiedzeń odbywających się w ramach przedpołudniowych obrad wygłoszono 240 referatów, których każdego dnia słuchała około pięciotysięczna publiczność ${ }^{70}$.

Poszczególne problemy będące przedmiotem wystapień zostały szczegółowo przytoczone przez Eugenię Sokolnicką i Teodorę Męczkowska. Nie wszyscy autorzy relacji we właściwy sposób odczytali różnorodność poruszanej problematyki. Wyraźnie zdegustowana tym chaosem była wspomniana wyżej Sokolnicka. Nie dostrzegła ona bowiem tego, że celem organizatorek było zwrócenie uwagi na rozwój programowy ruchu kobiecego, który wymuszał wyeksponowanie dotychczasowych osiagnięć i nowych obszarów działalności, co z kolei pociagnęło za soba rezygnację $z$ uchwalania końcowych rezolucji. To przesłanie musiało być mimo

69 E.S., Walka o prawo wyborcze... (cd.)..., op. cit., s. 329.

70 P.K.R., Międzynarodowe zjazdy kobiet. I..., op. cit., s. 667. 
wszystko czytelne, skoro na łamach zachowawczego „Kraju” zauważył je Józef Wassercug ${ }^{71}$.

Obrady w sekcjach obejmowały także dyskusje, które ujawniły wiele rozbieżnych stanowisk zwłaszcza w odniesieniu do sytuacji robotnic (sekcja III) i pozycji politycznej kobiet (sekcja IV). Wymiany zdań nie przewidziano natomiast podczas popołudniowych niebiletowanych i otwartych dla publiczności wykładów, którym przyświecał cel propagandowy. Charakter informacyjno-edukacyjny miały też zorganizowane pierwszy raz w ramach międzynarodowych kongresów kobiet, a zauważone tylko przez Kuczalską-Reinschmit, zebrania uświadamiające dla dziewcząt. W wygłaszanych wówczas referatach zwracano uwagę słuchaczkom na konieczność wyboru zawodu i zdefiniowania celu w życiu, ale zgodnego $z$ własnymi poglądami i predyspozycjami. Podkreślano edukacyjne wartości angażowania się w działalność społeczną oraz znaczenie dobrego przygotowania do roli matki. Edukacja i samodzielność ekonomiczna będące konsekwencja pracy zawodowej miały - jak głoszono - dać również kobietom swobodę w wyborze małżonka ${ }^{72}$. Kongres zdominowany został więc przez kwestie społeczne, które odgrywały kluczową rolę w umiarkowanym programie jego organizatora, czyli Niemieckiego Zwiazku Stowarzyszeń Kobiecych.

\section{Program ruchu kobiecego}

Zogniskowanie obrad Kongresu wokół zagadnień edukacyjnych i społeczno-opiekuńczych stworzyło szansę na ukazanie innego oblicza programów emancypacyjnych, bliższych tradycyjnym formom obecności kobiet w sferze publicznej, co w praktyce oznaczało także stonowanie wizerunku ruchu kobiecego, nad którym ciążł formułowany coraz głośniej w Wielkiej Brytanii i Stanach Zjednoczonych postulat równouprawnienia politycznego obu płci. Liczne referaty podsumowujace dotychczasowe osiagnięcia stowarzyszeń we wspomnianych dziedzinach stwarzały autorkom i autorom relacji możliwość wyeksponowania tych, które uważali za istotne i wartościowe. W analizowanych publikacjach można jednak dostrzec pewne elementy wspólne podkreślajace te nurty aktywności, które się spotkały $z$ największym zainteresowaniem, jak i takie, których

\footnotetext{
71 Widz, op. cit., s. 12.

72 P.K.R., Międzynarodowe zjazdy kobiet. I..., op. cit., s. 668-669.
} 
uwypuklenie oddawało odmienne zapatrywania piszacych na tzw. kwestię kobiecą.

Upowszechniany w relacjach program (albo poprzez szersze omówienie, albo przez określone hierarchizowanie i problematyzowanie zagadnień) wiązał się $z$ działalnością afirmująca rolę kobiety jako matki. Kwestia ta poruszana była w różnych aspektach, w tym też w odniesieniu do samotnego macierzyństwa, pozycji prawnej matek niezamężnych i sytuacji ich dzieci. Drugi krag zagadnień dotyczył edukacji i wychowania dziewcząt, głównie w kontekście przygotowania do pracy zarobkowej, co było połaczone ze wskazywaniem nowych zawodów (np. ogrodnictwo, praca w urzędach telegraficznych, pocztowych, zajmowanie się nauka, pielęgniarstwo), w tym również nawiązujących do promowanej wyraźnie aktywności kobiet wpisującej się w program kształtującej się wówczas nowoczesnej pracy socjalnej.

Narrację eksponującą wspomniane kwestie można odnaleźć nie tylko na łamach „Bluszczu”, „Tygodnika Mód i Powieści” czy „Kraju”, lecz także tytułów postępowo-radykalnych: „Przeglądu Tygodniowego”, „Prawdy”, „Ogniwa” i „Głosu”. Tygodniki należące do tej ostatniej grupy, a dokładnie pierwsze trzy z wymienionych, przywołuja też referat poświęcony koedukacji, wygłoszony przez przedstawicielkę Finlandii dr Maikki Fribey, gdzie ten typ nauczania realizowany był $z$ sukcesem od lat osiemdziesiatych XIX w. ${ }^{73}$ Nowość tę odnotowała także Żmijewska, jej komentarz w „Bluszczu” był jednak odmienny od tego, jaki towarzyszył tej informacji na łamach tygodników postępowo-radykalnych. Starała się ona bowiem umniejszyć widoczny podczas obrad entuzjazm towarzyszący idei wspólnego nauczania dziewcząt i chłopców, przywołując negatywne skutki takiej reformy. Nie oznacza to bynajmniej, że charakter tygodnika rzutował na odmienne komentowanie problemów poruszanych podczas obrad. Przykładem może być eksponowane zarówno w relacji Żmijewskiej, jak i Wassercuga oraz Sokolnickiej kwestii walki z prostytucją i alkoholizmem. Podobne zbieżności w wymowie narracji zostały jednak zdominowane przez różnice. W tygodnikach skierowanych do postępowej i radykalnej inteligencji odnaleźć można np. takie kwestie,

${ }^{73}$ Od 1904 r. wyraźnie wzrosło zainteresowanie koedukacja na ziemiach polskich. Jej zwolenniczkami były Męczkowska i Centnerszwerowa (zob. K. Dormus, Koedukacja - teoria i praktyka na ziemiach polskich na poczatku XX wieku, „Rozprawy z Dziejów Oświaty” 2004, R. 43, s. 53-92). 
które na łamach innych zostały przemilczane. Należą do nich postulaty zrównania zakresu edukacji oraz praw nauczycieli i nauczycielek, hasło takiego samego wynagrodzenia dla kobiet i mężczyzn za tę samą pracę, konieczność zakładania schronisk dla niezamężnych matek, ogródków dziecięcych czy biur ochrony prawnej dla kobiet.

W niektórych relacjach $z$ Kongresu zwracano także uwage na jego mieszczański charakter, czyli takie ukierunkowanie programowe, które pozwalało zjednywać do ruchu kobiety z kręgów inteligencko-burżuazyjnych. Element ten podkreśliły w swoich relacjach Sokolnicka, Moszczeńska, Centnerszwerowa, jak również na łamach „Tygodnika Mód i Powieści” Męczkowska. Autorki te zwróciły uwagę na to, że co prawda zajmowano się problemami zwiąanymi $z$ sytuacja robotnic, jednak bez ich udziału. Sokolnicka napisała wprost, że podczas Kongresu pogwałcono prawa kobiet pracujacych, a wykluczenie $z$ obrad działaczek demokratycznych, jak nazywano socjaldemokratki (poza kilkoma wyjątkami), wywołało ich manifestacje pod hasłem bezużyteczności obrad ${ }^{74}$.

$\mathrm{Na}$ tym aspekcie Kongresu skupiła się też Centnerszwerowa. Na łamach „Niwy Polskiej” podkreślała, że mimo haseł solidarności, obrady zamiast zjednoczyć działaczki z różnych warstw społecznych, powiększyły jeszcze przepaść między robotnicami a przedstawicielkami mieszczaństwa. Kongres ujawnił również, że te ostatnie nie wypracowały jednolitego stanowiska wobec ważkiego problemu spajającego kwestię kobieca $z$ kwestią robotnicza, mianowicie stosunku do praw ochronnych dla pracujacych w fabrykach matek. Zagadnienie to wyeksponowane zostało nie tylko w „Prawdzie”, lecz także na łamach „Tygodnika Mód i Powieści”. Pisząca do niego Męczkowska w swej tezie, której podporządkowana była jej narracja, nawiazała do wspomnianej wyżej krytyki Kongresu jako formuły nadającej ramy współpracy międzynarodowej kobiet. Wydaje się jednak, że zwróciła uwagę na ten problem tylko po to, aby wyrazić swoja negatywna opinię na temat tych działaczek, które nie liczą się z rzeczywistością i w imię zasady równości obu płci odmawiają robotnicom-matkom szczególnej ochrony prawnej ${ }^{75}$.

Moszczeńska odniosła się też do tej kwestii. Stała się ona dla niej punktem wyjścia do stwierdzenia, że jednak mimo różnic współpraca ruchu mieszczańskiego i proletariackiego jest możliwa, ale tylko wów-

\footnotetext{
74 E.S., Walka o prawo wyborcze... (cd.)..., op. cit., s. 329.
}

75 T.M., op. cit., s. 363. 
czas, jeżeli jej płaszczyznami będa rodzina, macierzyństwo i opieka nad dziećmi, czyli te obszary życia, które według niej sa sferami przyporządkowanymi kobiecie ${ }^{76}$. Wspólne działania byłyby możliwe, gdyby między kobietami z obu warstw społecznych panowały stosunki partnerskie. Tych jednak, jak twierdziła Centnerszwerowa, między przedstawicielkami mieszczaństwa i klasy pracującej nie było. Kongres potwierdził, że relacje między nimi opierały się na formule paternalistycznej, w myśl której kobiety $z$ kręgów burżuazyjno-inteligenckich miały się czuć odpowiedzialne za sytuację pracownic fabryk. Stąd też propagowanie podczas obrad instytucji pomocowych czy związków spożywców mających uwrażliwić na trudne warunki pracy i życia rodzin proletariackich ${ }^{77}$.

Kwestie zwiąane $z$ rozejściem się dróg programowych działaczek mieszczańskich i socjaldemokratycznych nie zostały dostrzeżone w większości relacji. Informowali o tym tylko piszacy na łamach „Prawdy”, „Głosu” i „Niwy Polskiej”, a więc tytułów zwiąanych z lewa strona sceny politycznej. Wyjątkiem był „Tygodnik Mód i Powieści” - jak można przypuszczać - głównie za sprawa samej autorki relacji, zwolenniczki równouprawnienia. Poruszanie tej drażliwej kwestii nie zmieniało jednak nadrzędnej wymowy zarówno tych narracji, jak i pozostałych, niekiedy krytycznych wobec Kongresu. Właściwie wszystkie, chociaż z różnym natężeniem, zwracały uwagę na powiązanie programów emancypacyjnych $z$ działalnością społeczną kobiet. Łączenie dążenia do poprawy ich sytuacji i statusu $z$ tą sfera aktywności miało być wyrazem postępu, jaki się dokonał w ruchu kobiecym, który zajał się realnymi potrzebami zrodzonymi przez postęp cywilizacyjny.

Relacje $z$ Kongresu stwarzały jednak mylny obraz międzynarodowego ruchu kobiecego. Marginalizowały bowiem postulat praw politycznych i wiążące się z nimi dyskusje. Próbą stworzenia właściwej perspektywy do oceny ruchu były więc tylko relacje, które poza Kongresem komentowały szerzej także postulat praw wyborczych dla kobiet.

\section{Stosunek do praw wyborczych kobiet}

Kwestia praw wyborczych kobiet dzieliła środowisko działaczek, czego wyrazem była również oddzielna konferencja sufrażystek. Związek

\footnotetext{
76 M., op. cit., s. 440.

77 R. Cent..., op. cit., s. 404.
} 
Niemieckich Stowarzyszeń Kobiecych organizujący Kongres berliński w swoim programie nie kwestionował zasadności postulatu praw wyborczych, a jedynie odsuwał jego realizację w bliżej nieokreślona przyszłość. Prawa polityczne kobiet nie zostały zreszta wyrugowane $z$ obrad Kongresu, gdyż - jak już wyżej wspomniano - znalazły swoje miejsce w programie sekcji IV. W analizowanych relacjach kwestia ta była jednak komentowana nie tyle przy okazji omawiania jego obrad, ile konferencji sufrażystek, co w praktyce oznacza, iż tylko część z nich odniosła się do tego postulatu.

Jak już wyżej wspomniano, konferencja sufrażystek była relacjonowana przez organy postępowej i radykalnej inteligencji, tj. „Przegląd Tygodniowy”, „Prawdę”, „Ogniwo” i „Niwę Polska”. Komentarze zamieszczone na łamach tych tytułów potwierdzały konieczność przyznania praw wyborczych kobietom. Jednak piszący dla dwóch pierwszych tytułów (Stanisław Kelles-Krauz i Eugenia Sokolnicka) wyraźnie osadzali tę kwestię w kontekście równouprawnienia płci, co można wiąać zarówno z obliczem ideowym wspomnianych tygodników, jak i przynależnościa piszacych do środowiska socjalistów. Opinie zawarte w „Ogniwie” (Pauliny Kuczalskiej-Reinschmit) i w mniejszym stopniu w „Niwie Polskiej” (Róży Centnerszwerowej) tłumaczyły z kolei zasadność nadania kobietom prawa do głosowania w kategoriach konieczności dziejowej wynikającej z postępu cywilizacyjnego.

Wśród organów radykalnej inteligencji zastanawia przemilczenie tej kwestii na łamach „Głosu”. W opublikowanej tam specyficznej relacji, bo przecież poświęconej nie tyle obradom, ile ocenie niemieckiego ruchu kobiecego, nie ma żadnej wzmianki na ten temat, chociaż wiadomo, że jej autorka nie była przeciwniczka praw wyborczych kobiet. Można tylko przypuszczać, że wymowne milczenie Moszczeńskiej, jak i sama koncepcja artykułu wynikały $z$ ograniczeń narzuconych jej przez redakcję "Głosu”, która w połowie 1904 r. znalazła się pod wpływem SDKPiL. Dla Moszczeńskiej, patrzącej na sprawę kobieca przez pryzmat postulatów liberalnych i narodowych, oznaczało to zakończenie współpracy z tym tytułem i odejście $z$ grona stałych współpracowników, co nastąpiło jeszcze w 1904 r. ${ }^{78}$

78 W. Bułat, op. cit., s. 71, 74. Zob. P. Samuś, Socjalistki w Królestwie Polskim przełomu XIX i XX w. Szkic do portretu zbiorowego [w:] Kobieta $i$ świat polityki. Polska na tle 
W tytułach, które komentowały konferencję sufrażystek, odniesienia do kwestii praw wyborczych pojawiły się także w ramach omawiania przebiegu Kongresu Kobiet. Nie poświęcono jej już jednak zbyt dużo miejsca. Wyjattkiem była Paulina Kuczalska-Reinschmit, która skorzystała $z$ okazji, by odnotować opinie innych znanych działaczek i wesprzeć nimi postulat równouprawnienia politycznego płci. Przywołała ona bowiem słowa Carrie Chappmann Catt, która twierdziła, iż kobiety wybieraja posłów o wyższej wartości moralnej, zaś słowami May Wright Sewall przestrzegła przed zawiązywaniem sojuszów ze stronnictwami politycznymi, które mogą jedynie skłócić środowisko sufrażystek ${ }^{79}$.

Najpoczytniejsze $z$ tygodników, czyli magazyny ilustrowane, tj. „Tygodnik Ilustrowany” i „Wędrowiec”, dystansowały się natomiast od kwestii praw wyborczych kobiet. O ile drugi $z$ wymienionych przemilczał tę sprawę, chociaż jego relacja na temat Kongresu wyrażała zdecydowane poparcie ruchu kobiecego, o tyle relacja Julii Kisielewskiej piszacej dla najpopularniejszego $z$ analizowanych pism została właściwie zdominowana przez ten temat, jej wydźwięk był jednak daleki od oczekiwań sufrażystek. Co ciekawe, autorka relacji nie należała do grona przeciwniczek praw wyborczych kobiet. Być może więc pod presją redakcji „Tygodnika Ilustrowanego" tak zbudowała narrację w artykule, by - nie wyrażając swojej opinii - wywołać u czytelników przekonanie, że jest to postulat, którego nie należy popierać. Efekt ten uzyskała przez przytaczanie przykładów i opinii innych. $Z$ jej artykułu wynika bowiem, że w Wielkiej Brytanii obawiano się dopuszczenia kobiet do urn wyborczych ze względu na przekonanie, że wywoła to przewrót w życiu społecznym i chaos. W tych częściach Australii, gdzie postulat ten został już wcielony w życie, miało zaś dojść do obniżenia jakości życia politycznego, gdyż głosami kobiet wprowadzono do parlamentu wiele nieodpowiednich osób. Zwieńczeniem narracji był argument ze świata nauki, Kisielewska zacytowała bowiem jednego z profesorów fizjologii i anatomii, który twierdził, że każda płeć ma odrębne, sobie właściwe zajęcia ${ }^{80}$.

Podobny charakter ma tekst zamieszczony na łamach „Tygodnika Mód i Powieści”. Nie chodzi tu jednak o relację Męczkowskiej, która - być

porównawczym $w$ XIX i w początkach XX wieku, red. A. Żarnowska, A. Szwarc, Warszawa 1994, s. 191-217.

79 P.K.R., Międzynarodowe zjazdy kobiet. I..., op. cit., s. 668.

80 J.O., op. cit., s. 506. 
może pod wpływem redakcji - wymownie milczała na temat praw wyborczych kobiet, mimo że nie należała do ich przeciwniczek. Dwa tygodnie przed jej artykułem, w ramach zapowiedzi mającego się odbyć w Berlinie Kongresu, opublikowano tekst Sprawa głosowania kobiet ${ }^{81}$. Jego autor (nazwiska nie udało się ustalić), podobnie jak Kisielewska, również odwołuje się do strategii argumentacyjnej typu „przykład innych”. Pozornie można bowiem odnieść wrażenie, że popiera przyznanie kobietom czynnych i biernych praw wyborczych, ostatecznie jednak wiedzie czytelnika do konkluzji wskazującej, że kobiety nie są przygotowane do uczestniczenia w życiu politycznym i zamyka artykuł stwierdzeniem: Często bardzo dobijamy się o przywilej, z którym następnie gdy go już posiądziemy nie wiemy co robić sami.

Podobnie odczytać należy wymowę relacji opublikowanej na łamach „Bluszczu”. Chociaż Eugenia Żmijewska właściwie pomija kwestię praw politycznych kobiet, to jednak - by uciąć wszelkie rozważania na ten temat - stwierdza, że jakiekolwiek zmiany w tej dziedzinie może przynieść tylko nacisk opinii publicznej, a ta z kolei dopiero musi zrozumieć konieczność wprowadzenia takich reform ${ }^{82}$. Wynika więc $z$ tego, że tygodniki przeznaczone dla kobiet nie dyskredytowały postulatu praw wyborczych. Jednoznacznego sprzeciwu nie odnajdziemy bowiem ani na łamach „Tygodnika Mód i Powieści”, ani w „Bluszczu”. Sugerowały natomiast konieczność edukacji politycznej kobiet i przeprowadzenia akcji uświadamiającej w całym społeczeństwie.

Spośród omawianych tygodników tylko w publikacji zamieszczonej na łamach „Kraju” można zauważyć negatywne nastawienie do równouprawnienia politycznego kobiet ${ }^{83}$, co może dziwić, zważywszy że autor artykułu Józef Wassercug wymieniany jest wśród współpracowników założonego w 1905 r. przez Teodorę Męczkowską Polskiego Stowarzyszenia Równouprawnienia Kobiet ${ }^{84}$.

$Z$ analizy powyższych tekstów wynika więc, że opinie formułowane przy okazji berlińskiego zjazdu działaczek organizacji kobiecych na temat praw wyborczych kobiet podporzadkowane były przede wszystkim linii programowej pisma. Tam, gdzie zachodził wyraźny rozdźwięk między

\footnotetext{
81 K., Sprawa głosowania kobiet, „Tygodnik Mód i Powieści” 1904, R. 46, s. 316-317.

82 E. Żm., op. cit., s. 319.

83 Widz, op. cit., s. 12.

84 C. Walewska, Ruch kobiecy $w$ Polsce, cz. 2, Warszawa 1909, s. 35-36.
} 
charakterem tytułu a poglądami osób relacjonujących wydarzenia, można zauważyć tendencję albo do przemilczenia tej kwestii (Moszczeńska na łamach „Głosu” oraz Męczkowska w „Bluszczu”), albo też unikania wypowiadania własnych sądów poprzez odwołanie się do poglądów innych (Kisielewska na łamach „Tygodnika Ilustrowanego”). Wyjątkiem był Józef Wassercug, który, co prawda, pisał na temat zjazdu kobiet w tonie entuzjastycznym, ale właśnie dlatego, że podczas jego obrad tylko w niewielkim stopniu mówiono o równouprawnieniu politycznym płci.

Warto jeszcze zwrócić uwagę na zasięg społecznego oddziaływania poszczególnych tytułów w kontekście promowania określonego podejścia do kwestii praw wyborczych. Tygodniki popierajace ten postulat („Przegląd Tygodniowy”, „Prawda”, „Ogniwo”, „Niwa Polska”) ukazywały się łącznie w nakładzie 6700 egzemplarzy, tytuły występujące przeciw niemu („Tygodnik Ilustrowany”, „Tygodnik Mód i Powieści”, „Kraj”) wydawano natomiast w nakładzie 32500 egzemplarzy. Pisma, które nie komentowały tej kwestii („Głos”, „Wędrowiec”, „Bluszcz”) i nie wspierały przemian w mentalności społeczeństwa polskiego, miały łączny nakład około 19 tys. egzemplarzy. Oznacza to, że wymiar propagandowy relacji prasowych na temat wydarzeń berlińskich był niewielki i społecznie ograniczony.

\section{Podsumowanie}

Kongres $\mathrm{i}$ inne wydarzenia związane $\mathrm{z}$ międzynarodowym ruchem kobiecym, które miały miejsce w Berlinie w 1904 r., dały pretekst do tego, by na łamach tygodników opublikowane zostały artykuły odnoszące się do kwestii coraz wyraźniej obecnej w dyskursie publicystyczno-literackim Królestwa Polskiego. Tylko część opiniotwórczych tytułów uważała jednak za istotny postulat przedefiniowania roli kobiet formułowany w kręgach postępowej inteligencji. Poczytne pisma katolickie, konserwatywne, ludowe przemilczały berliński zjazd działaczek. Najbardziej popularny i wysokonakładowy „Tygodnik Ilustrowany” również daleki był od formułowania poparcia dla ruchu kobiecego, w tym zwłaszcza postulatu praw wyborczych. Można więc ostrożnie stwierdzić, że recepcja programów emancypacyjnych tuż przed wybuchem rewolucji 1905-1907 była jednak społecznie ograniczona. Tygodniki, których relacje $z$ wydarzeń berlińskich wspierały ruch kobiecy, miały niski nakład i adresowane były do tych kręgów, którym i tak bliska była tzw. kwestia kobieca. Za tytuły 
mogące mieć wpływ na renegocjowanie społecznego odbioru ruchu kobiecego należy zaś uznać „Wędrowca” i konserwatywny „Kraj”. Pierwszy $z$ nich przedstawił Kongres szerokiemu gronu swoich czytelników jako przejaw $w$ zasadzie już bezspornych dążen do otwarcia kobietom drzwi do wszystkich zawodów i wszystkich praw. Drugi zaś nie tylko nie przemilczał Kongresu, lecz także - za pośrednictwem relacji Wassercuga wyraźnie wspierał ruch kobiecy, chociaż tylko dlatego, że podczas obrad powstało wrażenie wycofania się działaczek $z$ postulatów politycznych i zaangażowania się przede wszystkim $\mathrm{w}$ rozwiązywanie problemów społecznych.

$Z$ przeprowadzonych analiz wynika, że relacje dotyczace wydarzeń berlinskich kształtowane były przede wszystkim przez profil tygodnika, co powodowało, że ich autorki i autorzy nie zawsze mogli wyrażać swoje poglądy. Teodora Męczkowska, pisząc dla „Tygodnika Mód i Powieści”, wymownie milczała na temat praw wyborczych kobiet, mimo że niedługo później stanęła na czele stowarzyszenia stawiającego sobie takie właśnie cele.

Wydaje się, że ruch kobiecy, zwłaszcza w wymiarze międzynarodowym, wciąż traktowano jako ciekawostkę „zza oceanu”, wymysł ekscentrycznych Amerykanek, coś, co rozgrywa się w „świecie kobiet” dziejącym się gdzieś obok. $Z$ drugiej jednak strony relacje Pauliny Kuczalskiej-Reinschmit czy Eugenii Sokolnickiej skierowane do inteligencji zwiazanej ze środowiskami liberalnymi i socjalistycznymi ukazuja coraz większą sprawność organizacyjną owego „równoległego świata”, dojrzewanie poglądów, budowę nowych struktur. Międzynarodowe kongresy kobiet integrowały środowiska działaczek i budowały ich zbiorowa świadomość zawierająca się w podmiocie zbiorowym „my”. Jej wyrazem stawała się ukształtowana podczas obrad wspólnota celów i dążeń, wynikająca często $z$ internacjonalizacji nowych idei i obszarów działalności wypracowanych w warunkach narodowej specyfiki określonych stowarzyszeń. Artykuły prasowe dotyczace berlińskiego Kongresu Kobiet należy więc traktować nie tyle jako narzędzie kształtowania świadomości, ile przede wszystkim jako „pas transmisyjny” programu czy też programów emancypacyjnych, przenoszacy je poza środowisko działaczek, dla którego podobną rolę upowszechniająco-integrującą odgrywały pisma, organy poszczególnych stowarzyszeń kobiecych. Kluczową rolę w tym kontekście miała wymowa wielu relacji, które łączyły ruch kobiecy nie $z$ postulatami równościowymi, ale $z$ działalnością społeczną, edukacyjna i opiekuń- 
czo-wychowawcza ukierunkowana na rodzinę, dzieci oraz same kobiety. Kongres berliński umocnił więc przekonanie, że ruch kobiecy nie przekreśla tradycyjnych ról społecznych, co więcej - afirmuje macierzyństwo, które stało się misja społeczną kobiet, co na ziemiach polskich miało szansę być głównym argumentem zjednującym mu nowe zwolenniczki.

\section{Bibliografia}

\section{Źródła}

Kelles-Krauz Kazimierz, Listy, t. 2: 1898-1905, red. Feliks Tych, Wrocław : Ossolineum, 1984, ISBN 8304020157.

Lischnewska Maria, Der internationale Frauenkongreß in Berlin vom 19. bis 26. September 1896 [w:] Die Lehrerin in Schule und Haus. Centralorgan für die Interessen der Lehrerinnen und Erzieherinnen im In- und Auslande, red. Marie Loeper-Housselle (30 Jg, 1896-1897), Gera-Leipzig : Verlag von Theodor Hofmann, 1897, s. 99-106.

Sieroszewski Wacław, Szkice podróżnicze i wspomnienia, Kraków : Wydawnictwo Literackie, 1959.

Stritt Marie, Der Internationale Frauen-Kongress in Berlin 1904. Bericht mit ausgewählten Referaten, Berlin : Verlag von Carl Kabel, 1905.

Walewska Cecylia, Ruch kobiecy $w$ Polsce, cz. 2, Warszawa : Wydawnictwo Gebethner i Wolff, 1909.

\section{Źródla prasowe}

„Bluszcz” 1904, nr 27.

„Kraj” 1904, nr 24.

„Niwa Polska” 1904, nr 30.

„Ogniwo" 1904, nr 24; nr 25; nr 26; nr 28.

„Prawda” 1904, nr 27; nr 28.

„Przegląd Tygodniowy” 1904, nr 29.

„Tygodnik Ilustrowany” 1904, nr 22; nr 28.

„Tygodnik Mód i Powieści” 1904, nr 27; nr 31.

„Wędrowiec” 1904, nr 27. 


\section{Opracowania}

Adamczyk Danuta, Prasa jako narzędzie oddziaływania warszawskich środowisk opiniotwórczych i politycznych na prowincje w II połowie XIX i poczatkach XX wieku (na przykładzie Kielc i guberni kieleckiej), „Kwartalnik Historii Prasy Polskiej” 1990, t. 29, z. 1, s. 71-82, ISSN 0137-2998.

Anculewicz Zbigniew, Świat i ziemie polskie $w$ oczach redaktorów $i$ wspótpracowników „Kuriera Warszawskiego” w latach 1868-1915, Warszawa : ASPRA, 2002, ISBN 8388766392.

Blobaum Robert, „Kwestia kobieca” w Królestwie Polskim (1900-1914) [w:] Działaczki społeczne, feministki, obywatelki... Samoorganizowanie się kobiet na ziemiach polskich do 1918 roku (na tle porównawczym), red. Agnieszka Janiak-Jasińska, Katarzyna Sierakowska, Andrzej Szwarc, Warszawa : Neriton, 2008, s. 37-56, ISBN 978-83-7543-026-4.

Brykalska Maria, Aleksander Świętochowski. Biografia, t. 2, Warszawa : PIW, 1987, ISBN 83060015088.

Brykalska Maria, Aleksander Świętochowski redaktor „Prawdy”, Wrocław : Zakład Narodowy im. Ossolińskich, 1974.

Brykalska Maria, „Niwa”, 1872-1905 [w:] Zwierciadło prasy. Czasopisma polskie XIX wieku o literaturze rosyjskiej, red. Bohdan Galster [et al.], Wrocław : Zakład Narodowy im. Ossolińskich, 1978, s. 241-260.

Bułat Wojciech, „Głos” Jana Władysława Dawida 1900-1905, „Rocznik Historii Czasopiśmiennictwa Polskiego" 1966, t. 5, z. 2, s. 66-83, ISSN 0035-7669.

Dormus Katarzyna, Koedukacja - teoria i praktyka na ziemiach polskich na początku XX wieku, „Rozprawy z Dziejów Oświaty” 2004, R. 43, s. 53-92, ISSN 0080-4754.

Dybel Pawel, Eugenia Sokolnicka, Internetowy Słownik Biograficzny [online], [Dostęp: 30.01.2018]. Dostępny w World Wide Web: <http://bit. ly/2KyPG2b>.

Dziki Sylwester, Eugenia Żmijewska (1865-1923). Materiały do słownika dziennikarzy i publicystów polskich, „Zeszyty Prasoznawcze” 1965, R. 6, nr 3 (25), s. 64, ISSN 0555-0025.

Fell Alison S., Sharp Ingrid, Introduction: The Women's Movement and the First World War [w:] The Women's Movement in Wartime. International 
Perspectives, 1914-19, red. Alison S. Fell, Ingrid Sharp, Basingstoke : Palgrave Macmillan, 2007, ISBN 978-0-230-01966-9.

Franke Jerzy, Polska prasa kobieca $w$ latach 1820-1918. W kregu ofiary i poświęcenia, Warszawa: Wydawnictwo SBP, 1999, ISBN 8387629294. Garlicka Aleksandra, Matecznik niepokornych (Adam Wiślicki), „Kwartalnik Historii Prasy Polskiej” 1991, t. 30, z. 3/4, s. 71-84, ISSN 0137-2998.

Gawin Magdalena, Spór o równouprawnienie kobiet (1864-1919), Warszawa : Neriton, 2015, ISBN 978-83-7543-389-0.

Gehmacher Johanna, Moderne Frauen, die Neue Welt und der alte Kontinent. Käthe Schirmacher reist im Netzwerk der Frauenbewegung, „Österreichische Zeitschrift für Geschichtswissenschaften” 2011, t. 22, z. 1, s. 16-40, ISSN 1016-765X.

Gerhard Ute, National oder International. Die internationalen Beziehungen der deutschen bürgerlichen Frauenbewegung, „Feministische Studien” 1994, Heft 2, s. 34-52, ISSN 2365-9920.

Jałmużna Tadeusz, Julia Kisielewska - nauczycielka $i$ wychowawczyni [w:] Historia, spoleczeństwo, wychowanie. Ksiega pamiatkowa dedykowana Profesorowi Józefowi Miaso, red. Kalina Bartnicka [et al.], Pułtusk-Warszawa : Oficyna Wydawnicza ASPRA-JR, 2004, s. 241-245, ISBN 838806794X.

Jaszczuk Andrzej, Spór pozytywistów z konserwatystami o przyszłość Polski 1870-1903, Warszawa : PWN, 1986, ISBN 83-01-06342-4.

Kersting Christa, Weibliche Bildung und Bildungspolitik: das International Council of Women und seine Kongresse in Chicago (1893), London (1899) und Berlin (1904), „Paedagogica Historica” 2008, t. 44, nr 3, s. 327-346, ISSN 00309230.

Kinnebrock Susanne, „Wahrhaft international?" Soziale Bewegungen zwischen nationalen Öffentlichkeiten und internationalem Bewegungsverband [w:] Politische Netzwerkerinnen. Internationale Zusammenarbeit von Frauen 1830-1960, red. Eva Schöck-Quinteros, Anja Schüler, Annika Wilmers, Kerstin Wolff, Berlin : Trafo, 2017, s. 27-55, ISBN 978-389626-641-5.

Kmiecik Zenon, Nowoczesny konserwatysta (Erazm Piltz), „Kwartalnik Historii Prasy Polskiej" t. 30, 1991, z. 3/4, s. 91-96, ISSN 0137-2998. 
Kmiecik Zenon, Oblicze społeczno-kulturalne tygodnika „Wędrowiec” (18861905), „Kwartalnik Historii Prasy Polskiej” 1983, t. 23, z. 4, s. 43-56, ISSN 0137-2998.

Kmiecik Zenon, Prasa warszawska $w$ latach 1886-1904, Wrocław : Zakład Narodowy im. Ossolińskich, 1989, ISBN 83-04-0304-3.

Kmiecik Zenon, Problematyka spoleczno-polityczna pism konserwatystów warszawskich (1908-1914), „Kwartalnik Historii Prasy Polskiej” 1979, t. 18, z. 2, s. 63-80, ISSN 0137-2998.

Kmiecik Zenon, „Tygodnik Ilustrowany” w latach 1886-1904, „Kwartalnik Historii Prasy Polskiej” 1982, t. 21, z. 3/4, s. 25-42, ISSN 0137-2998.

Kmiecik Zenon, Wydawnictwa periodyczne $w$ Królestwie Polskim $w$ latach 1868-1904, „Rocznik Historii Czasopiśmiennictwa Polskiego” 1965, t. 4, z. 2, s. 155-159, ISSN 0035-7669.

Kołodziejska Zuzanna, „Izraelita” (1866-1915). Znaczenie kulturowe i literackie czasopisma, Kraków : Wydawnictwo Uniwersytetu Jagiellońskiego, 2014, ISBN 9788323338291.

Kulak Teresa, Trybuna umiarkowanego feminizmu. „Bluszcz” pod kierownictwem redakcyjnym Zofii Seidlerowej w latach 1906-1918 [w:] Kobieta i media. Studia $z$ dziejów emancypacji kobiet, red. Piotr Perkowski, Tadeusz Stegner, Gdańsk : Wydawnictwo Uniwersytetu Gdańskiego, 2009, s. 70-92, ISBN 978-83-7326-602-5.

Kwiatkowska Magdalena, Udział redakcji warszawskich czasopism kulturalno-społecznych $w$ rozpowszechnianiu ksiażki naukowej $w$ drugiej połowie XIX i na poczatku XX wieku, „Acta Universitatis Lodziensis. Folia Librorum" 2005, t. 12, s. 5-33, ISSN 0860-7435.

Lech Adam, Społeczne konstruowanie rzeczywistości obiektywnej, „Zeszyty Naukowe Politechniki Ślaskiej”, seria: „Organizacja i Zarządzanie” 2015, z. 65, s. 183-195, ISSN 1641-3466.

Lipska Maria, Loth Roman, „Ogniwo” 1902-1905: bibliografia zawartości, „Materiały Bibliograficzne” 1957, t. 6, s. V-XXX.

Nałęcz Daria, Życiorys konsekwentny (Józef Wassowski), „Kwartalnik Historii Prasy Polskiej” 1992, t. 31, z. 3/4, s. 203-208, ISSN 0137-2998.

Orecka Katarzyna, Prasa dla kobiet jako odzwierciedlenie zmiany roli i pozycji kobiety $w$ dziewiętnastowiecznym społeczeństwie [w:] Przeszłość - Teraźniejszość - Przyszłość. Problemy badawcze młodych politologów, red. 
Dominika Mikucka-Wójtowicz, Kraków : Wydawnictwo Libron, 2010, s. 23-35, ISBN 9788372716354.

Rosner Katarzyna, Narracja jako struktura rozumienia, „Teksty Drugie: teoria literatury, krytyka, interpretacja” 1999, t. 56, nr 3, s. 7-15, ISSN 08670633.

Rupp Leila J., Worlds of Women. The Making of an International Women's Movement, Princeton : Princeton University Press, 1997, ISBN 0-69101676-3.

Samuś Paweł, Socjalistki w Królestwie Polskim przełomu XIX i XX w. Szkic do portretu zbiorowego [w:] Kobieta $i$ świat polityki. Polska na tle porównawczym $w$ XIX i w poczatkach XX wieku, red. Anna Żarnowska, Andrzej Szwarc, Warszawa : Wydawnictwo DiG, 1994, s. 191-217, ISBN 83-85490-24-8

Schüler Anja, Wolff Kerstin, „Es sind die gleichen Überzeugungen, die die Frauen aller Länder erfüllen..." Zur Entstehung von internationalen Netzwerken in den Frauenbewegung [w:] Politische Netzwerkerinnen. Internationale Zusammenarbeit von Frauen 1830-1960, red. Eva Schöck-Quinteros, Anja Schüler, Annika Wilmers, Kerstin Wolff, Berlin : Trafo, 2017, s. 20, ISBN 978-3-89626-641-5.

Sierakowska Katarzyna, „Nowe Słowo” - trybuna emancypantek polskich [w:] Działaczki społeczne, feministki, obywatelki... Samoorganizowanie się kobiet na ziemiach polskich do 1918 roku (na tle porównawczym), red. Agnieszka Janiak-Jasińska, Katarzyna Sierakowska, Andrzej Szwarc, Warszawa : Neriton, 2008, s. 69-79.

Sierakowska Katarzyna, Ruch kobiecy a rewolucja 1905 roku [w:] Dziedzictwo rewolucji 1905-1907, red. Anna Żarnowska [et al.], Warszawa-Radom, 2007, s. 255-275, ISBN 9788387516628.

Sikorska-Kowalska Marta, „Ogniwo” 1902-1905. „Legalna ekspozytura” PPS [w:] Polityka i politycy w prasie XX i XXI wieku. Prasa organizacji politycznych, red. Małgorzata Dajnowicz, Adam Miodowski, Białystok : Wydawnictwo HUMANICA, 2017, ISBN 9788394617738.

Sokół Zofia, Z badań nad polska prasa kobieca w latach 1818-1939, „Kwartalnik Historii Prasy Polskiej” 1983, t. 22, z. 3, s. 5-12, ISSN 0137-2998. Stegner Tadeusz, Środowiska liberalne w Królestwie Polskim wobec kwestii kobiecej w dobie rewolucji lat 1905-1907 [w:] O kobietach. Studia i szkice. 
Wiek XIX $i$ XX, red. Jadwiga Hoff, Rzeszów : Wydawnictwo Uniwersytetu Rzeszowskiego, 2011, s. 103-119, ISBN 9788373386396.

Tobera Marek, Poseł prawdy (Aleksander Świętochowski), „Kwartalnik Historii Prasy Polskiej" 1991, t. 30, z. 3/4, s. 62-70, ISSN 0137-2998.

Zawiszewska Agata, Aktivitätsmodelle der deutschen Frauenbewegung um die Wende vom 19. zum 20. Jahrhundert in Gesellschaftlicher und Publizistischer Tätigkeit von Paulina Kuczalska-Reinschmit, „Colloquia Germanica Stetinensia” 2016, nr 25, s. 101-120, ISSN 2450-8543. 